\title{
ObtainingAntioxidants from Botanic Matrices Applying Novel Extraction Techniques
}

\author{
Moyses N. Moraes, Giovani L. Zabot, Juliana M. Prado, M. Ange la A. Meire les* \\ School of Food Engineering, University of Campinas, UNICAMP, R. Monteiro Lobato, 80, CEP: 13083-862, Campinas, SP/Brazil
}

\begin{abstract}
Botanic matrices are abundant sources of antioxidants which have the capacity to avoid the lipid oxidation of food and present remarkable health benefits. The natural antioxidants might be obtained applying many extraction techniques. Satisfactory results of obtaining extracts with antioxidant properties and high yields using modern extraction techniques are shown by recent studies. The selection of the suitable technique depends on the desired class of substances to be extracted. In this overview, the advances reached in scientific researches involving natural antioxidants are presented. The advantages and potential applications of four novel extraction techniques: Supercritical Flu id Extraction, Pressurized Liquid Extraction, Microwave Assisted Extraction and Ultrasound Assisted Extraction are discussed, considering the characteristics of the target compounds. These techniques reduce the solvent consumption and abridge the extraction time. Consequently, the process productivity is increased.
\end{abstract}

Keywords Antioxidants, Bioactive Compounds, Flavonoids, Phenols, Phytochemicals, Pressurized Liquid Extraction, Supercritical Fluids

\section{Introduction}

The interest in the prevention of chronic diseases, such as cancer, has led to modifications in the nutritional composition of foods in the last years. These modified foods are classified as functional foods because they contain, besides the basic nutrition, components that provide health benefits[1]. The continued ingestion of food supplemented with antioxidant substances cause inhibitory effects on the proliferation of carcinogenic cells in human beings[2-4]. These effects appear because the antioxidant substances are able to perform some functions, as free radical scavenging, peroxide decomposition, suppression of singlet oxygen, enzymatic inhibition[1] and increasing the levels of endogenous defences [5].

In general, there are two categories of antioxidants: natural and synthetic. The natural antioxidants comprise a wide variety of substances found in the nature, such as polyphenols (flavonoids and phenolic acids), terpenoids and vitamins $\mathrm{E}$ and $\mathrm{C}$. The phenolic compounds present high antioxidant capacity in biologic and food systems, especially the flavonoids group[6].

The identification of the chemical composition of extractsfrom several botanic matrices that present agents with potential antioxidant properties has been the focus of

\footnotetext{
* Corresponding author:

meireles@fea.unicamp.br (M. Angela A. Meireles)

Published online at http://journal.sapub.org/ph

Copyright (C) 2013 Scientific \& Academic Publishing. All Rights Reserved
}

many studies in food and health fields. So me antio xidants are thermolabile, sensitive to light and they interact with polar and nonpolar solvents by different mechanisms. These characteristics can change the extraction yield and the quality of the extract recovered. The objective of this overview is to report the advantages associated with some modern extraction techniques for obtain ing natural antioxid ants. The extraction technique more suitable for the extraction of a given target group is indicated.

\section{Natural Antioxidants and Their Health Benefits}

In this section, the beneficial health effects exercised by phytochemical compounds with antioxidant properties are brie fly gathered. Epidemio logic studies showingexperiment al evidences of the relationship between better health and diets rich in food containing these phytochemicals are referenced. Emphas is is given to recent studies which show the current results of ingesting natural antioxidants as polyphenols, terpenoids and vitamin E.

\subsection{Polyphenols}

Polyphenols are defined as substances which contain an aromatic ring attached to one or more hydroxyls, including their functional derivatives[7]. A wide variety of phenolic derivatives with antioxidant capacity is found in botanic matrices, including simple phenols, benzoic and cinnamic acids derivatives and flavonoids. 


\subsubsection{Flavonoids}

Flavonoids are secondary metabolites of low molecular massproduced by plants, which belong to the class of phenolic compounds and present high antioxidant activity[7]. They act as antioxidants because they have many active sites to scavenge free radicals[8]. The flavonoids are divided into groups according to their chemical structures, as flavones and isoflavones, flavanones, flavonols, flavanols and anthocyanins (Table 1).

Living organis ms have an oxidation-reduction system necessary to keep the level of generated free radicalsconstant. The formation of free radicals in higher levels than the ideal induces cellular oxidative stress that leads to lipid peroxidation of the cellular membrane, which can cause degenerative diseases and aging[9]. Therefore, scientific investigations search for solutions to avoid the cellular oxidation by the supplementation of antio xidant compounds in food. There are evidence that flavanols, flavanones and anthocyanidins have beneficial effects to the memory, perception and neurodegeneration[10].

Hemodialysis patients face an elevated risk of cancer, ascribed in part to increased oxidative stress. Anthocyanins, present at high amounts in red fru its, show a good efficacy on the reduction of the oxidative damage in these individuals through the decrease on the risks of DNA oxidation and on the lipid and protein peroxidation[11].

Saponarin, an antio xidant belonging to the flavones group and that was recently found in barley leaves, inhibited the malonaldehyde formation. In a normal reaction, malonaldeh yde is formed from oxidized lipids on the skin surface by ultraviolet irradiation[12].

Naringin, a dietetic flavanone, is an effective antioxidant for the prevention of oxidative stress and for the protection against liver carcinogenesis in rats[13]. In human beings, phenolic extracts obtained from apple and grape containing flavonoids showed potential protection of lung cells exposed to the oxidative stress[14].

Proanthocyanidins extracted from blueberry (Vaccinium angustifolium) are able to reduce the cognitive function loss by the protection against the deficient $\mathrm{Ca}^{2+}$ recovery and moderate oxidative / inflammatory stress signalling[15]. Flavonoids extracted from fennel (Foeniculum vulgare) present antitumoral effect by modulating the lipid peroxidat ion[16]. Flavonoids extracted from carob (Ceratonia siliqua), mostly the miricetin, caused biochemical changesin rats physiologic system, suggesting protection of liver and renal cells by the capacity of free radicals scavenging[17].

Flavanols extracted from lychee (Litchi chinensis) were supplemented on the diet of 20 healthy male long-distance runners. The decrease of the cellular oxidative stress and the reduction of the tissue damage caused by high-intensity exerc ise training were observed[18].

\subsubsection{Non-flavonoids}

The non-flavonoids compounds are phenolic acids which present a functional carboxy 1 group, divided into benzo ic and cinnamic acids derivatives[7]. Hydroxycinnamic acids are present in many foods, such as coffee, yerba mate, apple and plum(Table 1)[19]. The phenolic acids present importa nt biologic and pharmacologic properties, particularly on cancer prevention[20].

Caffeic acid, a hydroxycinnamic acid found in high concentrations in fruits and coffee beans, induces the apoptosis of human breast cancer cells[21]. The use of this phytochemical for the protection against disturbances of the antioxidant defense system has been tested as the possible mechanis $m$ whereby botanic compounds slow down the skin aging process. Pretreatment of skin cells with caffeic acid prior UVA (ultraviolet A) irradiation inhibits cytotoxicity, induction of metalloprotease-1 (enzy me responsible for the damage caused on collagen) and free radicalsgeneration[22].

Ferulic acid is a powerful phenolic antioxidant and photo-protector obtained from plants such as corn, rice, tomato, peanut, apple, orange and pineapple. Ferulic acid decreases the absorption of UVB (ultrav iolet B) radiation on human epidermis and inhibits the formation of tumors, because this compound blocks the secretion of cytokines generated after the skin is exposed to the UVB radiation[23].

\subsection{Terpenoids}

Terpenoids are classified according to the number of carbon atoms in their chain. $\beta$-carotene and lycopene are tetraterpenoids (carotenoids formed by 40 carbons)[24]. The main vegetal sources of carotenoids and their molecular structures are listed in Table 1.

Scientific evidences link the antioxidant properties of carotenoids with their beneficial effect against chronic diseases. Annatto (Bixa orellana) extract, constituted by carotenoids with bixin as major co mpound, was identified as a potential therapeutic agent for modulation of the equilibrium of reactive oxygen and nitric oxide species, two substances that induce diabetes[25]. Annatto constituents were also studied as toxic agents against a wide variety of tumor cells. Cis-bixin has the capacity of inhibiting the enzy mes associated with the oxidative stress [26].

Experimental assays point out that lycopene can protect the organism against damages caused by the exposure to tobacco[27],[28], and it is beneficial on the treatment of acute and chronic pancreatitis by reducing intracellular free radicals [29]. $\beta$-carotene can help the prevention of prostate cancer[30]and gastric carcinoma[31].

\subsection{Vitamin $\mathrm{E}$}

The supplementation with vitamin $\mathrm{E}$ in the diet of 180hea lthy elderly people during 4 months apparently alleviates the oxidative stress by improving the erythrocyte membrane fluidity and by reducing the erythrocyte hemolysis[32]. Vitamin E tested in rats inhibited the formation of oxygen reactive species, decreased the level of lipid peroxide, increased the levels of glutathione and lipid peroxidation enzymes and presented the capacity to prevent the mitochondrial apoptosis [33].

Vitamin E identified in garlic extract was tested against the cellular oxidative stress in rats. This phytochemical 
helped on the protection of the liver structural integrity due to free radicals scavenging capacity[34]. Other beneficial health effects provided by vitamin E include cardiovascular diseases prevention[35], chemo preventive actions against skin cancer[36] and induction of apoptosis of carcinogenic pancreatic cells[37]. All forms of vitamin E are able to induce antioxidant effects and to protect food and biologic memb ranes against the lipid pero xidation[38].

Table 1. Classification of Some Antioxidant Compounds

\begin{tabular}{|c|c|c|c|}
\hline $\begin{array}{l}\text { Antioxi dant } \\
\text { Compoun ds }\end{array}$ & Basic Stru ctu re & Examples & Main Sources \\
\hline Flavones & & $\begin{array}{c}\text { Luteolin }\left(\mathrm{R}_{1}=\mathrm{R}_{2}=\mathrm{R}_{3}=\mathrm{R}_{4}=\right. \\
\mathrm{OH}), \text { Apigenin }\left(\mathrm{R}_{1}=\mathrm{R}_{2}=\mathrm{R}_{4}\right. \\
\left.=\mathrm{OH} ; \mathrm{R}_{3}=\mathrm{H}\right) \text { and Tangeret in } \\
\left(\mathrm{R}_{1}=\mathrm{R}_{2}=\mathrm{R}_{3}=\mathrm{OCH}_{3} ; \mathrm{R}_{4}=\right. \\
\mathrm{H})\end{array}$ & $\begin{array}{c}\text { Parsley and Celery[39]; } \\
\text { Lemon[40]; } \\
\text { Tangerine[41]; } \\
\text { Orange[42]; Oregano[43]; } \\
\text { Rosemary[44]; Pepper[45] }\end{array}$ \\
\hline Flavanones & & $\begin{array}{c}\text { Hesperitin }\left(\mathrm{R}_{1}=\mathrm{OCH}_{3} ; \mathrm{R}_{2}=\right. \\
\mathrm{OH}) \text { and Naringenin }\left(\mathrm{R}_{1}=\right. \\
\left.\mathrm{OH} ; \mathrm{R}_{2}=\mathrm{H}\right)\end{array}$ & $\begin{array}{l}\text { Lemon[46]; Tomato[47]; } \\
\text { Spearmint[48]; } \\
\text { Orange[49]; } \\
\text { Tangerine[50]; Lime[51] }\end{array}$ \\
\hline Flavonols & & $\begin{array}{c}\text { Quercet in }\left(\mathrm{R}_{1}=\mathrm{R}_{2}=\mathrm{R}_{3}=\mathrm{R}_{4}\right. \\
\left.=\mathrm{OH} ; \mathrm{R}_{5}=\mathrm{H}\right) \text {, Miricet in }\left(\mathrm{R}_{1}\right. \\
\left.=\mathrm{R}_{2}=\mathrm{R}_{3}=\mathrm{R}_{4}=\mathrm{R}_{5}=\mathrm{OH}\right) \text { and } \\
\text { Kaempferol }\left(\mathrm{R}_{1}=\mathrm{R}_{2}=\mathrm{R}_{4}=\right. \\
\left.\quad \mathrm{OH} ; \mathrm{R}_{3}=\mathrm{R}_{5}=\mathrm{H}\right)\end{array}$ & $\begin{array}{c}\text { Chamomile[52]; Yerba } \\
\text { Mate[53]; Cashew[54]; } \\
\text { Apple[55]; } \\
\text { Strawberry[56]; } \\
\text { Spinach[57]; Tomato[47]; } \\
\text { Rosemary[44]; } \\
\text { Oregano[43] }\end{array}$ \\
\hline Anthocyanins & & $\begin{array}{c}\text { Cyanidin }\left(\mathrm{R}_{1}=\mathrm{R}_{2}=\mathrm{R}_{4}=\mathrm{R}_{5}=\right. \\
\left.\mathrm{R}_{7}=\mathrm{OH} ; \mathrm{R}_{3}=\mathrm{R}_{6}=\mathrm{H}\right) \\
\text { Pelargonidin }\left(\mathrm{R}_{1}=\mathrm{R}_{3}=\mathrm{R}_{6}=\right. \\
\left.\mathrm{H} ; \mathrm{R}_{2}=\mathrm{R}_{4}=\mathrm{R}_{5}=\mathrm{R}_{7}=\mathrm{OH}\right) \\
\text { and Malvidin }\left(\mathrm{R}_{1}=\mathrm{R}_{3}=\right. \\
\mathrm{OCH}_{3} ; \mathrm{R}_{2}=\mathrm{R}_{4}=\mathrm{R}_{5}=\mathrm{R}_{7}= \\
\left.\mathrm{OH} ; \mathrm{R}_{6}=\mathrm{H}\right)\end{array}$ & $\begin{array}{c}\text { Grape[58]; Raspberry[59]; } \\
\text { Cherry[60]; } \\
\text { Strawberry[56]; } \\
\text { Jabuticaba[61]; } \\
\text { Pomegranate[62]; } \\
\text { Plum[63] }\end{array}$ \\
\hline Catechins & $\mathrm{OH}$ & $\begin{array}{c}\text { Epicatechin }\left(\mathrm{R}_{1}=\mathrm{R}_{2}=\mathrm{R}_{3}=\right. \\
\left.\mathrm{OH} ; \mathrm{R}_{4}=\mathrm{H}\right)\end{array}$ & $\begin{array}{c}\text { Spearmint[48]; Cocoa[64]; } \\
\text { Strawberry[56]; } \\
\text { Apple[55]; Green and } \\
\text { White Tea[53] }\end{array}$ \\
\hline$\beta$-carotene & & - & $\begin{array}{l}\text { Carrot and Sweet } \\
\text { Potato[65]; Beet, Turnip, } \\
\text { Pear and Peach[66]; } \\
\text { Apricot[67]; Papaya[68]; } \\
\text { Pumpkin[69]; Buriti, } \\
\text { Taioba, Caruru, Mint, } \\
\text { Parsley and Tucumã[70] }\end{array}$ \\
\hline Lycopene & & - & $\begin{array}{c}\text { Tomato[71]; Papaya[72]; } \\
\text { Watermelon[73]; } \\
\text { Guava[74];Pit anga and } \\
\text { Mari[70] }\end{array}$ \\
\hline Vitamin E & & $\begin{array}{c}\alpha \text {-Tocopherol }\left(\mathrm{R}_{1}=\mathrm{R}_{2}=\mathrm{R}_{3}=\right. \\
\left.\mathrm{CH}_{3}\right) \text { and } \beta-\text { Tocotrienol }\left(\mathrm{R}_{1}=\right. \\
\left.\mathrm{R}_{3}=\mathrm{CH}_{3} ; \mathrm{R}_{2}=\mathrm{H}\right)\end{array}$ & $\begin{array}{c}\text { Sunflower[75]; } \\
\text { Peanut[76]; Soybean[77]; } \\
\text { Lettuce[78]; Banana[79] }\end{array}$ \\
\hline $\begin{array}{l}\text { Hydroxycin- } \\
\text { namic acids }\end{array}$ & & $\begin{array}{c}\text { Coumaric Acid }\left(\mathrm{R}_{1}=\mathrm{OH} ; \mathrm{R}_{2}\right. \\
=\mathrm{H}), \text { Caffeic Acid }\left(\mathrm{R}_{1}=\mathrm{R}_{2}=\right. \\
\mathrm{OH}) \text { and Ferulic Acid }\left(\mathrm{R}_{1}=\right. \\
\left.\mathrm{OCH}_{3} ; \mathrm{R}_{2}=\mathrm{OH}\right)\end{array}$ & $\begin{array}{l}\text { Cherry[80]; Coffee[81]; } \\
\text { Melon[82]; Apple[55]; } \\
\text { Yerba Mate[53]; } \\
\text { Strawberry[56]; } \\
\text { Grape[58];Pepper[45] }\end{array}$ \\
\hline
\end{tabular}




\section{Modern Techniques for Extraction of Antioxidants}

Antioxidants are substances that, in low concentrations, inhibit or prevent the oxidation of other substances[83]. Many foods still contain synthetic antioxidants in their formulations, as Butylated Hydroxytoluene (BHT) and Butylated Hydroxyanisole (BHA), because they are thermally stable and of low cost. However, experimental investigations show that BHT and BHA are carcinogenic and cytotoxic above $500 \mathrm{ppm}[84]$. The maximum recommended BHT daily intake is $0.125 \mathrm{mg} / \mathrm{kg}$ of body mass and the maximum recommended BHA daily intake is $0.5 \mathrm{mg} / \mathrm{kg}$ of body mass. In the European Union the use of BHT and BHA in food prepared for babies and young children is not allowed[85].

Due to these issues, natural antioxidants allowing for the substitution of synthetic antioxidants are the target of many studies [86-91]. Boo et al [92] de monstrated high antioxidant activities of naturalp ig ments found in onion (Allium cepa L.), red cabbage (Brassica oleracea L.), mulberry (Morus alba L.), purple sweet potato (Ipomoea batatas L.), yellow paprika (Capsicum annuum L.), red beet (Beta vulgaris L.) and grape (Vitis vinifera L.).

Botanic matrices are abundant sources of nutraceutical compounds. The natural antioxidants, belonging to the GRAS (Generally Recognized As Safe) group of FDA (Food and Drug Admin istration), are extracted from herbs or plants and are commonly phenolic compounds that present health benefits, as the prevention of diabetes, cancer, hypertension, as thma and in fections [93],[94].

The separation or the isolation of the target compounds fro $m$ their orig inal matrix is the method used to obtain these antioxidant substances. Conventional extraction techniques (steam distillation and Soxhlet extraction, for instance) possess some drawbacks due to the use of high temperatures and/or high amounts of organic solvents; another limitation is that the steam distillation process can be used only to obtain volatile oils (mostly terpenes). These conventional techniques are being substituted by novel techniques, as supercritical fluid extraction (SFE)[95-98]; pressurized liquid extraction (PLE)[90],[99],[100]; microwave ass isted extraction (MAE)[101-103]; and ultrasound assisted extraction (UAE)[104],[105]. The choice of the suitable technique depends on: the desired class of compounds to be extracted; the structural characteristics of the botanic matrix (fru its, stems, seeds, leaves, root, flowers, etc.); the quality and yield required for the extract; the process conditions (temperature, pressure, etc.) and the economic feasibility for scaling up the process.

For instance, SFE using pure $\mathrm{CO}_{2}$ is more appropriate for extracting nonpolar compounds as terpenoids, tocopherols and sitosterols[106], while PLE is more appropriate for extracting polar antioxidants as the phenolic compounds: anthocyanins [107] and flavonols [108]] using solvents with high polarity. MAE is an extraction technique indicated when the botanic matrix contains large amounts of water, because the water is responsible for the absorption of the energy generated by the microwaves. This energy disrupts the cells and facilitates the release of chemical constituents[109]. The UAE technique is also suitable for obtaining antioxidants. The characteristic of UAE is the reduced solvent consumption[110], the possibility of processing several samples in the same equipment and the short extraction time [109].

The solvent selection for the extraction is based on some factors, as: physicochemical properties, availability, cost and toxicity. The choice of the ideal solvent should consider its selectivity, as well the solute solvating capacity, interfacial tension, viscosity, stability and reactivity[109].

\subsection{Historical Aspects}

The application of supercritical technology in obtaining bioactive compounds has evolved over the past decade. However, the divulgation of the investigations related to this area in patent form started in the early of 1970 when the first patent comprising a process for recovering caffeine from green coffee using carbon dioxide in supercritical conditions was registered by Zosel[111]. In 1981, another patent was published dealing with the decaffeination of coffee[112]. From that date to now, over than 300 patents were regis tered and are available at "Web of Knowledge" database. One of these recent patents comprises a useful method for preparing carotenoid microcapsules with a controllable isomeric ratio applying a supercritical fluid at high temperatures[113]. In the same way, another invention utilizes olive by-products for the isolation and separation of tocopherols with supercritical fluids[114]. In 1997, a inovative study was published dealing with the effects of ultrasound on mass transfer in SFE[115]. This coupled system has been investigated currently in the extraction of lutein esters from marigold [116] and of oil fro m adlay seed[117].

The number of scientific investigations published after the year 2000 comprising modern extraction techniques for obtaining antioxidants has significantly risen by 2012 . Figure 1 shows this tendency, whereby searches in "Scopus" and "Web of Knowledge" database inserting the terms "SFE and antioxidant" returned together more than 780 documents in the year 2012, while less than 80 documents covering the same subject were published in the year 2000. The same search procedures were used for PLE, MAE and UAE. These novel techniques also present an important evolution in the scientific scenario, mainly in the last five years where the number of publications related to MAE and UAE in Scopus, for instance,increased from 150 and 102 to 551 and 393, respectively. The participations of SFE, PLE, MAE and UAE in obtaining natural antio xidants referent to the overall techniques in 2003 have been $5.9 \%, 1.0 \%, 1.4 \%$ and $0.9 \%$, respectively. In 2012, these relative participations have increased to $9.5 \%, 4.3 \%, 7.5 \%$ and $5.4 \%$, respectively. Therefore, the contribution of both techniques in 2003 has been $9.2 \%$, while in 2012 it has been $26.7 \%$, almost 3 times higher than ten years ago. 

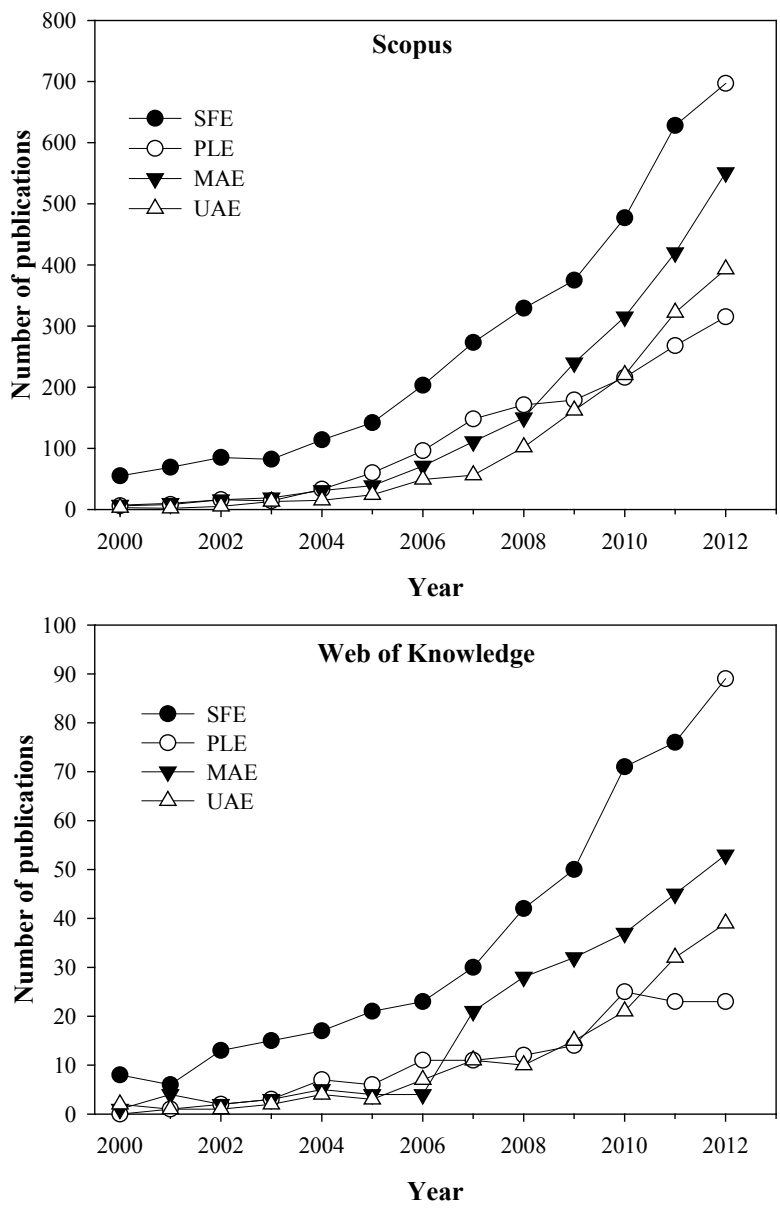

Figure 1. Number of documents published in Scopus and Web of Knowledge databases in the range of years 2000-2012onmodern techniques for the extraction of antioxidant compounds. SFE: supercritical fluid extraction; PLE: pressurized liquid extraction; MAE: microwave assisted extraction; UAE: ult rasound assisted extraction

\subsection{Supercritical Fluid Extraction (SFE)}

Extraction of bioactive compounds with conventional solvents is characterized by low selectivity and may require high temperature[118]. Because of these limitations, SFE has some characteristics that justify its use for obtaining natural antioxidants. $\mathrm{CO}_{2}$, the solvent mostly used in SFE, presents critical temperature of only $304 \mathrm{~K}$, which allowsits use for the extraction of thermo sensitive (thermolabile) compounds.Several phytochemicals show high solubility in $\mathrm{CO}_{2}$ around supercritical conditions ( $\left.304 \mathrm{~K} / 7.4 \mathrm{MPa}\right)$.

Bioactive compounds extracted from botanic matrices by SFE technique present a pronounced reproduction of the sensory characteristics of the raw material when co mpared to conventional techniques. The thermal degradation and the decomposition of thermolabile substances are strongly reduced, since the SFE procedure occurs at low temperatures and in the absence of oxygen and light. This feature is especially useful in the extraction of antioxidants, because it guarantees the conservation of their functionalproperties[11 9]. Moreover, SFE is more selective than the conventional extraction techniques, and it is suitable for obtaining solvent-free products[118].
Extraction of antioxidants with supercritical $\mathrm{CO}_{2}$ requires the use ofhigh pressures. At this condition, the co-extraction of other undesirable compounds, as waxes and oleoresins, might happen. When the co-extraction of these compounds cannot be avoided, several separator vessels can be displayed in series, operating at different temperature and pressure conditions, to fractionate the extract[120].

Belonging to the Lamiaceae family, rosemary (Rosmarin us officinalis) is a plant with powerful antioxidant agents. Carnosic acid (CA) and carnosol are the major phenolic diterpenes present in rosemary extracts obtained by SFE, as shown by Kuo et al.[121]. The CA content obtained in the referred study was approximately $110 \mathrm{mg} / \mathrm{g}$ extract, resulting in $\mathrm{IC}_{50}$ of $7.47 \mu \mathrm{g} / \mathrm{cm}^{3}$. The $\mathrm{IC}_{50}$ is the concentration of extract or active compound needed to inhibit $50 \%$ of oxidation of a defined substance, which can be determined by the DPPH (2,2-diphenyl-1-pic rylhydrazyl) test. $\mathrm{An} \mathrm{IC}_{50}$ of $7.47 \mu \mathrm{g} / \mathrm{cm}^{3}$ is very attractive, because low concentrations of $\mathrm{CA}$ present significant effects on the free radicals scavenging. At the concentration of $80 \mu \mathrm{g} / \mathrm{cm}^{3}, \mathrm{CA}$ presented inhibition of $84.1 \%$ of the lipid peroxidation, while the synthetic BHT antioxidant inhibited $80.8 \%$ of the lip id peroxidation.

The results obtained by Kuo et al.[121] corroborate the studies carried out by Vicente et al.[89] using rosemary leaves; the authors obtained high CA content in the extract in $1 \mathrm{~h}$ of extraction by SFE. The antioxidant activity of the extract increased with the extraction time because the volatile oil is depleted from the vegetal matrix at the beginning of the process, and the phenolic compounds, which present higher antioxidant activity, are only later extracted.

Antioxidants are compounds usually sensitive to light and heat. The antioxidants obtained by SFE have the advantage of being processed under the absence of light and at moderate temperatures. Furthermore, they are easily separat ed from the solvent and they hardly suffer undesirable oxidation reactions. Recently, natural antio xidants with high activity were obtained by SFE from mint (Mentha spicata L.)leaves[122],[123], coffee (Coffea arabica)grounds[96], green tea (Camellia sinensis) leaves[124], grape (Vitis vinifera L.) seeds [97], thyme (Thymus vulgaris)flowers [125], guava (Psidium guajava L.) seeds[86], orange (Citrus sinensis L.) bagasse[126] and rosemary (Rosmarinus officinalis) leaves[127].

The interest in SFE has been increasing in the last years, which is shown by the several studies found in literature dealing with this topic (Figure 1). One of SFE features is that the raw material must be dried prior to the extraction with supercritical $\mathrm{CO}_{2}$. The water decreases the effic iency of this technique by limiting the contact between the $\mathrm{CO}_{2}$ and nonpolar solutes[120]. The water present in the solid material may also compete with $\mathrm{CO}_{2}$ to dissolve the solute, which affects the mass transfer rate. Considering these aspects, the drying of the raw material at ideal conditions, without causing degradation of the bioactive compounds, is required[109]. 
Supercritical $\mathrm{CO}_{2}$ is a solvent appropriate to extract nonpolar solutes. Compounds presenting high molecular mass, as flavonoids, are poorly soluble in pure $\mathrm{CO}_{2}$. In such case, the addition of a polar cosolvent to the $\mathrm{CO}_{2}$, to form a mixture with it in ideal proportions, improves the solubility of polar organic compounds. Thus, the mixture $\mathrm{CO}_{2}+$ cosolvent can increase the mass transfer rate. The solubility improvement in the supercritical region is associated with mo lecular interactions, mostly hydrogen bonds [128].

The extraction of polyphenolic antioxidants by SFE with cosolvents was studied by various authors. Phenolic diterpenes were obtained from rosemary using $10 \%(\mathrm{w} / \mathrm{w})$ of ethanol[129] and flavones were extracted from chamomile (Matricaria recutita) using 20\% (w/w) of ethanol[130]. Water was employed as a cosolvent for extracting phenols from sweet basil (Ocimum basilicum)[131] and antioxidant compounds from sunflower (Helianthus annuus)[132] at proportions of $20 \%(\mathrm{w} / \mathrm{w})$ and $5 \%(\mathrm{w} / \mathrm{w})$, respectively.

Ethanol and water are the most appropriatesolvents to be applied in the food industry. Ethanol is widely used to increase the efficiency of the extraction of phenolic acids and flavonoids, and is easily removed from the final product by distillation[120],[133]. The cosolvents commonly used to extract antioxidant compounds are listed in Table 2.

Table 2. Cosolvents Used in Supercritical Fluid Extraction (SFE) of Antioxidant Compounds

\begin{tabular}{cccc}
\hline Cosolvent & Classof Compounds & EYI $^{\mathbf{a}}$ & Reference \\
\hline \multirow{2}{*}{ Ethanol } & Polyphenols & 14.0 & {$[96]$} \\
& Flavonoids & 2.2 & {$[130]$} \\
Ethyl Acetate & Phenolic Acids & 2.4 & {$[126]$} \\
Methanol & Phenolic Acids & 3.8 & {$[136]$} \\
Vegetable oils & Phenols & 4.0 & {$[137]$} \\
Water & Carotenoids & $3.0-3.7$ & {$[138],[139]$} \\
\hline
\end{tabular}

${ }^{a}$ Number of times the yield increases compared to the yield with pure $\mathrm{CO}_{2}$

The interactions between solute and solvent in the SFE process can be studied considering a solution of infinite dilution because the solubility of the bioactive compounds is low in supercritical $\mathrm{CO}_{2}$, and, moreover, usually the solution is far from saturation. This fact makes the equilibrium study simple in systems where only $\mathrm{CO}_{2}$ is used as solvent. On the other hand, the critical temperature and pressure change when cosolvent is added depending on its fraction in the mixture. As an example, for the system $\mathrm{CO}_{2}+$ ethanol the critical point moves from $310.6 \mathrm{~K}$ and $7.77 \mathrm{MPa}$ for 0.0044 mo $1 \%$ ethanol to $410.3 \mathrm{~K}$ and $15.17 \mathrm{MPa}$ for $0.403 \mathrm{~mol} \%$ ethanol[134]. The temperatures above $330 \mathrm{~K}$ are not recommended for processing thermo sensitive compounds, the existence of two phases inside the extractor is common when using high fractions of cosolvent. Despite the fact that the process can be performed using such system, in this caseit presents a behaviour that cannot be predicted by the models used for $\mathrm{CO}_{2}$ alone.Therefore, when using cosolvents the system is much more complex than for $\mathrm{CO}_{2}$ alone and each case should be individually studied. Increasing the cosolvent fraction above $50 \%$ changes the process to PLE, where ethanol is the solvent and $\mathrm{CO}_{2}$ is the cosolvent, when the latter is used.

Another recent trend concerning cosolvents is using vegetable oils as modifiers. In the extraction of carotenoids by SFE, it not only allows recovering compounds that have low solubility in $\mathrm{CO}_{2}$, but it also leads to the production of carotenoid-rich vegetable oils. Canola, olive, hazelnut, sunflower seed, soybean and rapeseed oils have been used for this purpose, among others[135].

\subsection{Pressurized Liquid Extraction (PLE)}

The PLE technique is an alternative that has been recently used to obtain bioactive compounds; it uses an aqueous or organic solvent at high pressure and/or temperature by circulating the solvent through the sample. High pressure is not the most important feature in PLE process. In fact, most often the purpose of raising the pressure is to keep the solvent in the liquid phase. Designations for PLE can be found in literature, as accelerated solvent extraction (ASE), pressurized hot solvent extraction (PHSE), pressurized water extraction (PWE), high pressure solvent extraction (HPSE) and subcritical solvent extraction (SSE), among others. Antioxidants can be obtained using solvents at temperatures above their boiling point. For these reasons, a generic term is used: "superheated solvent extraction" (SHSE) [140]. Liquid carbon dioxide cannot be used in this case because its critical temperature is low (at about $304 \mathrm{~K}$ ) compared to the temperatures used in PLE. So, at pressures and temperatures above the critical point of $\mathrm{CO}_{2}$ the process is called SFE.

Flavonoids, catechins, anthocyanins, flavanones, and flav ones are some of the phenolic compounds which were obtained using PLE[107],[108],[141-144]. King andGrabiel [145], in their patent, demonstrated the potential of PLE technique for extracting polyphenols from fruits and vegetables wastes. Also, a method for extraction of phenols from grape skins by ASE using ethanol-water mixtures is found in literature[146].

In PLE, high temperature is usually attractive, because it improves the extraction yield. The increase in temperature modifies the solvent dielectric constant and the solute solubility in the solvent[109]. Studies show that polyphenols extracted at temperatures above $363 \mathrm{~K}$ are unstable and can suffer pronounced thermal degradation, although the quantity of antioxidants extracted is high at elevated temperatures[107],[147],[148].

Comparative assays using PLE and conventional extraction techniques were carried out for obtaining the three major flavones (hesperitin, nobiletin and tangeretin) present in tangerine peels (Citrus reticulata). The flavones were efficiently extracted by PLE, reaching higher yields than the conventional methods. Additionally, the extraction time was lower for PLE[141].

The recovery of phenolic compounds from oregano leaves (Origanum vulgare) by PLE was tested by Miron et al.[149]. The operational conditions used in the experimental assays 
were temperatures of $323 \mathrm{~K}, 373 \mathrm{~K}, 423 \mathrm{~K}$ and $473 \mathrm{~K}$, and different proportions of ethanol/water as solvents. The extracts obtained using PLE with $100 \%$ of water in batch mode applying an $11 \mathrm{~cm}^{3}$ extractor at $323 \mathrm{~K}$ and $10 \mathrm{MPa}$ presented the highest amount of phenols and the highest antioxidant activity. Under these conditions, the total phenols content was $184.9 \mathrm{mg}$ GAE/g extract, where GAE means "gallic acid equivalents". The antio xidant activ ity was established as the amount of extract necessary to reduce the DPPH concentration in $50 \%$, resulting in $\mathrm{IC}_{50}$ of only 6.98 $\mu \mathrm{g} / \mathrm{cm}^{3}$. When pure ethanol was used as solvent at temperature of $373 \mathrm{~K}$, the total phenols content was only $102.2 \mathrm{mg}$ GAE$/ \mathrm{g}$ extract and the $\mathrm{IC}_{50}$ was $11.5 \mu \mathrm{g} / \mathrm{cm}^{3}$. These results suggest that the solvent and the temperature influenced both the extract yield and its quality[149].

Recovery of anthocyanins and phenolic compounds from jabuticaba (Myrciaria cauliflora) was studied applying PLE and Low-Pressure Solvent Extraction (LPSE). Similar yields were obtained using both techniques. However, the PLE technique was attractive because it resulted in a rapid process $(\approx 9 \mathrm{~min})$ and it allowed low solvent consumption. The content of anthocyanins and total phenols in PLE extract were 2.15 and 1.66 times higher, respectively, than their content in LPSE extract. Moreover, PLE extract resulted in cost of manufacturing 40 times lower than LPSE extract due to the short processing time[150].

PLE technique is usually appropriate for obtaining antioxidants from lignocellulosic materials. Some of the effects achieved under temperatures of hydrothermal treatment (for instance above $493 \mathrm{~K}$ ) are listed as[120]:

i) solubilizationof acid-solublelignin;

ii) hydrolytic depolymerization of hemicellulose into compounds of highmolecular mass (soluble fibers);

iii) extractionof lipophilic co mpounds;

iv) extraction of lignans;

v) extraction of non-saccharides as terpenes, fatty acids and monomeric phenols.

The phenolic compound vanillin was the major component with antioxidant activity found in barley husks subjected to non-isothermal auto-hydrolysis in aqueous medium[151]. The solubilized portion obtained in the auto-hydrolys is of pine (Pinus radiata) using several tests (DPPH radicalscavenging, hydroxyl radical scavenging, Trolo $x$ equivalent antio xidantcapacity, b-carotene bleaching and reducing power) presented specific antioxidant activity 40 times higher than BHT, 25 times higher than $\alpha$-tocopherol, 8 times higher than caffe ic acid, 3.5 times higher than BHA and 3 times higher than gallic acid[152].

PLE differs from conventional techniques because PLE uses high temperature and pressure in extractive process, which may be conducted in semi-continuous (dynamic) or batch (static) modes. A wide range of temperature might be applied; it usually varies between $293 \mathrm{~K}$ and $473 \mathrm{~K}$. The pressure commonly used varies between $3 \mathrm{MPa}$ and 20 $\mathrm{MPa}[153]$. Therefore, PLE is a suitable technique for extracting several solutes, both polar and nonpolar. PLE has been used as an alternative for obtaining antioxidant substances with high molecular mass derived from the hemicellulose frag mentation[120].

\subsection{Microwave Ass isted Extraction (MAE)}

MAE is another innovative technique that has been prese nting special interest. Microwaves consist of nonionizing electromagnetic energy with a frequency from $0.3 \mathrm{GHz}$ to $300 \mathrm{GHz}$ that is applied directly to the raw material. They transmit energy which penetrates into the biologic matrix and interacts with polar molecules, mostly water, generating heat; the heat expands and disrupts the vegetal cell, favoring the extraction of intracellular phytochemical compounds. MAE is a technique frequently used for extractigthermolabi le compounds [109].

Extraction of phenolic compounds from cherry (Prunus cerasus)pulp was performed using the MAE method in batch mode by Simsek et al.[103]. Epicatechin (flavanol) was the major phenolic compound extracted, and its concentration was higher when using the MAE technique than when using the conventional technique. The antioxidant efficiency of MAE extract was $28.32 \mathrm{mg}$ DPPH/g sample[103]. Antioxidants present in deoiled rosemary (Rosmarinus officinalis) leaves were extracted by MAE using ethanol and water as solvents. Carnosic acid and carnosol were responsible for most of the antioxidant activity found in the extract. The $\mathrm{IC}_{50}$ values using water and ethanol as solvents were $22.8 \mu \mathrm{g} / \mathrm{cm}^{3}$ and $41.0 \mu \mathrm{g} / \mathrm{cm}^{3}$, respectively[154].

Onion (Allium cepa) varieties are rich in quercetin (flavonol). Their flavonoids content and antioxidant activity were evaluated using MAE as the extraction technique. The red onion variety exhibited the highest antioxidant activity. According tothe DPPH test, the $\mathrm{IC}_{50}$ was $17.09 \mathrm{mg} / \mathrm{cm}^{3}$ and the total amount of quercetin extracted was $134.7 \mathrm{mg} / 100 \mathrm{~g}$ dried sample[155].

In a recent study, the antioxidant activity of polyphenol compounds present in pomegranate (Punica granatum) peels was evaluated using the MAE technique with water as solvent. Pronounced polyphenols yields were reached (210.4 mg GAE/g extract). The $\mathrm{IC}_{50}$ was $14.53 \mu \mathrm{g} / \mathrm{cm}^{3}$ (DPPH test), confirming an elevated antio xidant capacity of pomegranate extract[156].Figure 2 showsthe free radical scavenging capacity of the pomegranate extract evaluated by the DPPH test.The phenolic compounds extracted by MAE have activity equivalent to the synthetic BHT antioxidant in concentrations over $40 \mu \mathrm{g} / \mathrm{cm}^{3}$. At this concentration, the antioxidant activity of pomegranate extract and BHT were over $90 \%$, indicating $\mathrm{MAE}$ as a potential alternative for obtaining natural antioxidants.

The conventional solid-liquid extraction can generate undesirable residues with products. In addition, the extract cansuffer oxidative transformations during the solvent removal step[119]. Several scientific investigations report MAE applicability for obtaining natural antioxidants, without generating undesirable residues, as the extraction of polyphenols from peanut skins[157], whole tomato (Solanum spp.)[101], grape (Vitis vinifera) seeds [158], sweet potato (Ipomoea batatas) leaves[159] and bean (Phaseolus 
vulgaris L.)[160]. In general, the antioxidant activity of extracts obtained by MAE is higher than the activity of extracts obtained by conventional techniques, because the microwave treatment does not cause any deterioration of antioxidant properties of the extract[161].

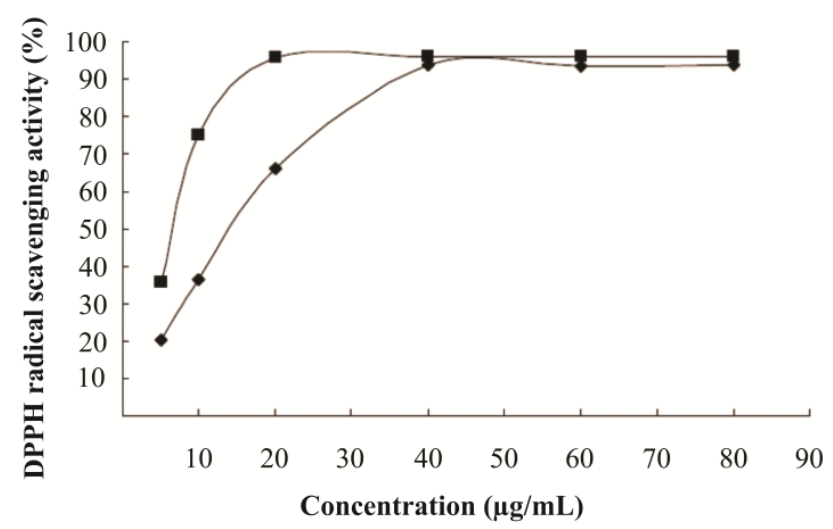

Figure 2. Free Radical Scavenging Activity of Pomegranate Polyphenols Obtained by Microwave-Assisted Extraction (-) and of the Synthet ic Antioxidant BHT (一-) $[156]^{1}$

MAE process is short, usually fro $\mathrm{m} 2 \mathrm{~min}$ to $40 \mathrm{~min}$. This fact makes MAE an attractivetechnique, since for thermolabile compounds long extraction times can result in degradation and consequent antioxidant capacity loss [101].

The results obtained using MAE are satisfactory because the mic rowaves cause molecular motion due to the migration of ionic species and dipole rotation. Therefore, the micro waves effect is proportional to the medium dielectric constant and to the solid matrix. In addition, the increase of the process temperature improves the solvent penetration [109].

Considering these aspects, the solvent selection should be made taking into account its dielectric constant. Polar molecules and ionic solutions have permanent dipole moment and strongly absorb the energy of microwaves. Therefore, ethanol, methanol and water are ideal solvents, while hexane and toluene have low dielectric constants and are not recommended for MAE[109],[162].

\subsection{Ultrasound Assisted Extraction (UAE)}

Most of extraction techniques consist of the manipulation of the solvent physical properties to reduce its superficial tension, to increase the solute solubility and to improve the mass transfer rate; in some cases, these manipulations also induce changes in the solvent polarity[109].

The UAE technique consists in using mechanic vibrations caused by sound waves with frequencies higher than $20 \mathrm{kHz}$. Sound waves are intrinsically different from electro magnetic waves, because the latter can propagate through the vacuum, while sound waves need a physical medium to propagate. The mechanic vibrations cause expansion and compression cycles in the medium, creating bubbles which collapse and cause cavitation, instantly creating a high local pressure and

\footnotetext{
${ }^{1}$ This figure is under the terms of the creative commons attributions license.
}

intense local heating. These fast changes induce disruption and thinning of the cell me mbranes, consequently increasing the mass transfer rate of organic substances from the solid matrix to the solvent[109],[163].

The advantages of UAE technique include the simplicity of the equipment and the possibility of using different solvents for the extraction, including water-ethanol mixtures[163]. In food and pharmaceutical fields, UAE is used to extract several bioactive compounds from botanic matrices, as flavonoids[104],[164],[165], polyphenols[166], [167], alkaloids[168], terpenoids[169] and anthocyanins [105],[170]. The improvement of extracting bioactive compounds when applying ultrasounds is attributed to the mass transfer rate increase due to the solvent cavitation induced by the ultrasounds wave passing through the medium[154].

An efficient extraction procedure for recovering antioxidant compounds from jabuticaba (Myrciaria cauliflora) skins was proposed in literature: 10 min of UAE + conventional agitated bed extraction (ABE). This combination maximized the extraction of polyphenols and resulted in extracts with high antioxidant activity. At $30 \mathrm{~min}$ of reaction (based on the couple oxidation of $\beta$-carotene and linoleic acid), the antioxidant activity of the extracts obtained using $\mathrm{UAE}+\mathrm{ABE}$ was over $85 \%$, while the $\mathrm{ABE}$ process presented extracts with antioxidant activity under $65 \%$. Furthermore, UAE + A BE was the best option from the economic point of view, because the extract obtained by this combined technique presented the lowest cost of manufacturing (US\$ 387.2/ $\mathrm{kg}$ of crude extract)[61].

Considerable concentrations of rosmarinic acid (6.36 $\left.\mathrm{mg} / \mathrm{cm}^{3}\right)$ and total phenols $(8,790 \mathrm{ppm} \mathrm{GAE})$ were obtained from deoiled rosemary (Rosmarinus officinalis) leaves applying the UAE technique and water as solvent. The high concentration of antioxidants in the extract resulted in high antioxidant activity and the $\mathrm{IC}_{50}$ was $23.6 \mu \mathrm{g} / \mathrm{cm}^{3}$. The $\mathrm{IC}_{50}$ was measured by DPPH test[154].

In extraction of leek (Allium porrum) stem by UAE, 69.5 mg GAE/g extractwas obtained. The antioxidant activity of the extract was compared to the standard antioxidants: vitamin $\mathrm{C}$ and $\mathrm{BHT}$. The $\mathrm{IC}_{50}$ value of the ethanolic extract was $61.1 \mu \mathrm{g} / \mathrm{cm}^{3}$. Although the $\mathrm{IC}_{50}$ value of the ethanolic extract was higher than the $\mathrm{IC}_{50}$ of vitamin $\mathrm{C}\left(\mathrm{IC}_{50}=10.6\right.$ $\left.\mu \mathrm{g} / \mathrm{cm}^{3}\right)$ and BHT $\left(\mathrm{IC}_{50}=39.2 \mu \mathrm{g} / \mathrm{cm}^{3}\right)$, the inhibition composition of the ethanolic extract was very low. Thus, the leek extracts can be used in the industry as efficient agents against oxidation[171].

A certain a mount of water $(40 \%-60 \%)$ should be added to the solvent in order to obtain satisfactory yields in UAE, because water increases the extraction of flavonoids and other polar compounds. Water addition increases the medium relative polarity and facilitates the propagation of the ultrasonic waves[110]. Using UAE with water as solvent was efficient for reaching specific hydroxylation of polyphenols and carotenoids in order to increase their bioactivity[172].

Ultrasound is also a broad method that can be done not 
only with solvent at atmospheric pressure. The co mbination of UAE followed by re-extraction of obtained extract by SFE was performed aiming to concentrate diterpenes present in sage extract. The diterpenes are generally considered to be responsible for antioxidant activity of the extracted compounds[173].

The coupled system of high-intensity ultras ound + SFE is an efficient manner of enhancing mass transfer in extraction processes. In this sense, a supercritical $\mathrm{CO}_{2}$ extraction of oil from particulate almonds was performed using power ultrasonic transducer with a frequency of $20 \mathrm{kHz}$. The process performance was evaluated, showing that this system conducted to a $30 \%$ increased yield[174]. The same procedure was used for obtaining extract from ginger. In the presence of ultrasound within the supercritical mediu m, both the extraction rate and the yield increased. Generally, the initial stage of extraction, which is controlled by the external mass transfer, is not affected by ultrasound. Nevertheless, in the subsequent stage of extraction, which is controlled by the internal mass trans fer, the u ltrasound allows an imp rovement in the yield[175]. Recently, extracts of malagueta pepper containing capsaicinoids were obtained using SFE and SFE assisted by ultrasound. The assays carried out with ultras ound pres ented a yield $20 \%$ higher[176].

\subsection{Summary of the Characteristics of S FE, PLE, MAE and UAE}

Table 3 shows compiled information in operational conditions of the four techniques presented for extracting antioxidants. This Table is a compendium of the arguments discussed in the text. The distinguishing characteristics that make each technique more or less attractive for processing different raw materials are also included in Table 3. For instance, SFE technique does not need cosolvent when the target phytochemicals are nonpolar (terpenoids, tocopherols and sitosterols). To extract polyphenols, on the other hand, the use of cosolvents is essential. Thus, the extract quality and yield are closely related to the extraction technique and to the process conditions.

Figure 3 exemp lifies the novel extraction techniques used for obtaining antio xidants: SFE, PLE, MAE and UAE. The basic schematic diagram of equipment used in each technique is presented. In the case of MAE, the extractor must be built of a material that allows the microwaves to propagate. This material is usually glass or teflon. MAEis mostly performed in batch mode (static), while the other techniques are usually performed in semi-continuous mode (dynamic), using constant solvent flow rate in the extraction vessel. The selection of the way to promote the extractor heating is done by the researchers; in the scheme of Figure 3, the extractors of SFE, PLE and UAE are heated using a jacket.

Table 4 shows the antioxidant capacity, expressed as $\mathrm{IC}_{50}$, of compounds obtained from several raw materials using the four novel extraction techniques discussed in the text. Several studies found out high antioxidant capacities of compounds in low concentrations. Certainly, the lower the $\mathrm{IC}_{50}$ value the larger the antio xidant capacity of the extract.
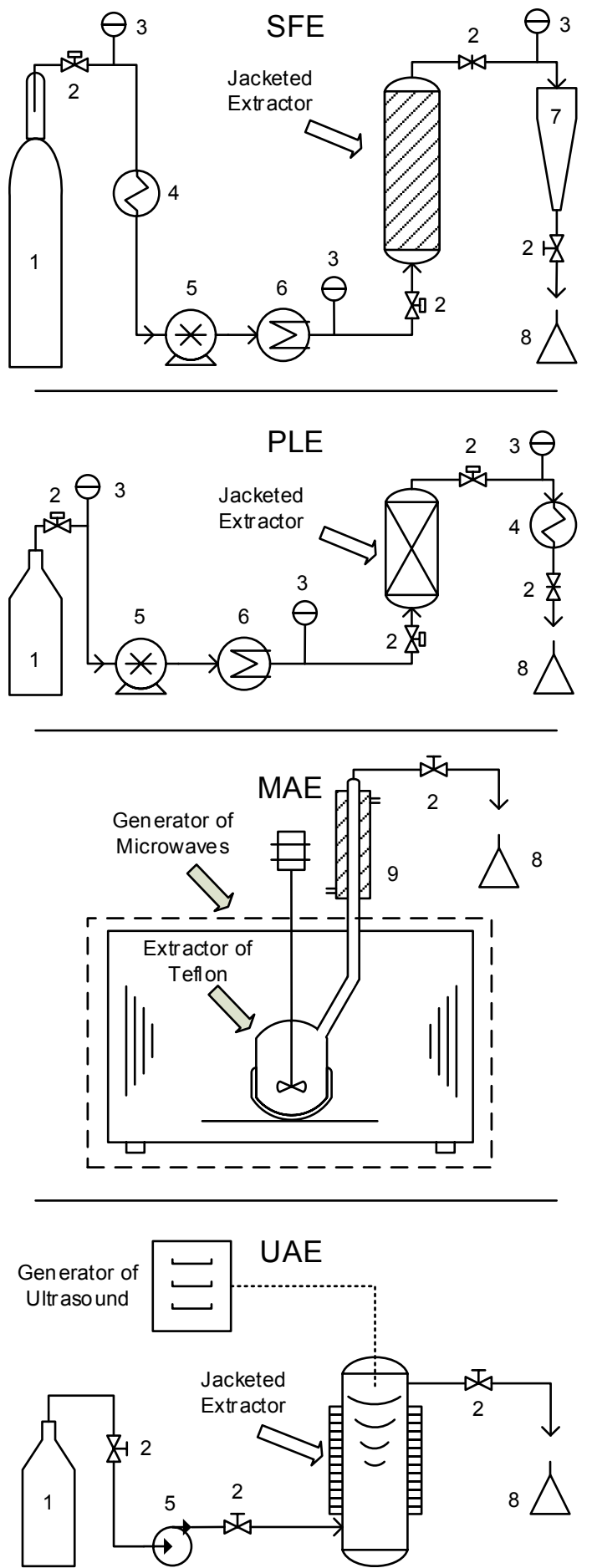

Figure 3. Basic Schematic Diagram of Equipment used for the Extraction of Natural Antioxidants. SFE: Supercritical Fluid Extraction; PLE: Pressurized Liquid Extraction; MAE: Microwave Assisted Extract ion; UAE: Ultrasound Assisted Extraction; 1: Solvent Reservoir; 2: Valve; 3:Pressure Gauge; 4: Cooling Bath; 5: Pump; 6: Heating Bath; 7: Separator Vessel; 8: Extract Collecting Vessel; 9: Condenser 
Table 3. Selection of the Extraction Technique and Operational Conditions Suitable for Obtaining Different Antioxidant Compounds

\begin{tabular}{|c|c|c|c|c|c|}
\hline Technique & Characte ristics & Botanic Matrix & Antioxidants & Con ditions & Reference \\
\hline \multirow{12}{*}{ SFE } & \multirow{2}{*}{$\begin{array}{l}\text {-Is Green and Sustainable } \\
\text { Technology } \\
\text {-Uses Moderate Temperatures }\end{array}$} & Turmeric Rhizome & Curcuminoids & $\begin{array}{l}\text { T: } 303 ; \text { P: } 30 ; \mathrm{S}: \mathrm{CO}_{2}+6.4 \%(\mathrm{w} / \mathrm{w}) \text { of Ethanol } \\
\text { + Isopropanol, } 1: 1 \mathrm{v} / \mathrm{v} ; \mathrm{Q}_{\mathrm{s}}: 4.2 \times 10^{-5} ; \mathrm{V}: 0.221\end{array}$ & [177] \\
\hline & & Rosemary Leaves & $\begin{array}{l}\text { Phenolic } \\
\text { Diterpenes }\end{array}$ & $\begin{array}{c}\mathrm{T}: 313 ; \mathrm{P}: 15 ; \mathrm{S}: \mathrm{CO}_{2}+10 \%(\mathrm{w} / \mathrm{w}) \text { of Ethanol; } \\
\text { Qs: } 1 \times 10^{-3} ; \mathrm{V}: 2\end{array}$ & [129] \\
\hline & \multirow{8}{*}{$\begin{array}{l}\text {-Extracts Light-Sensitive } \\
\text { Compounds } \\
\text {-Generates GRAS* Products } \\
\text { - Facilitates the Separation and } \\
\text { the Solvent Recycling } \\
\text {-Allows Selective Extraction } \\
\text { - Results in High-Purity Extracts } \\
\text {-Presents High Yields } \\
\text { - Is Suitable for Extracting } \\
\text { Nonpolar Compounds } \\
\text { - Results in High Yields of Polar }\end{array}$} & Sweet Basil Leaves & Phenols & $\begin{array}{c}\mathrm{T}: 302 ; \mathrm{P}: 20 ; \mathrm{S}: \mathrm{CO}_{2}+20 \%(\mathrm{w} / \mathrm{w}) \text { of Water; } \\
\text { Qs: } 8 \times 10^{-5} ; \mathrm{V}: 0.221\end{array}$ & [131] \\
\hline & & Chamomile Flowers & Flavones & $\begin{array}{c}\mathrm{T}: 323 ; \mathrm{P}: 68.9 ; \mathrm{S}: \mathrm{CO}_{2}+20 \%(\mathrm{w} / \mathrm{w}) \text { of } \\
\text { Ethanol; } \mathrm{Qs}: 1.8 \times 10^{8}\end{array}$ & [130] \\
\hline & & Clove Buds & Eugenol & $\mathrm{T}: 323 ; \mathrm{P}: 10 ; \mathrm{S}: \mathrm{CO}_{2} ; \mathrm{Qs}_{\mathrm{s}}: 6 \times 10^{-5} ; \mathrm{V}: 0.032$ & {$[178]$} \\
\hline & & Tomato Peels & Carotenoids & $\mathrm{T}: 363 ; \mathrm{P}: 40 ; \mathrm{S}: \mathrm{CO}_{2} ; \mathrm{Qs}_{\mathrm{s}}: 9 \times 10^{-8} ; \mathrm{V}: 0.01$ & [179] \\
\hline & & Tomato Seeds & Lycopene & $\mathrm{T}: 343 ; \mathrm{P}: 40 ; \mathrm{S}: \mathrm{CO}_{2} ; \mathrm{Qs}: 4.5 \times 10^{-8} ; \mathrm{V}: 0.01$ & {$[180]$} \\
\hline & & Melon Seeds & Tocopherols & $\mathrm{T}: 330 ; \mathrm{P}: 29 ; \mathrm{S}: \mathrm{CO}_{2} ; \mathrm{Qs}_{\mathrm{s}}: 6 \times 10^{-7} ; \mathrm{V}: 0.5$ & [181] \\
\hline & & Pressed Palm Fiber & Sitosterols & $\mathrm{T}: 313 ; \mathrm{P}: 30 ; \mathrm{S}: \mathrm{CO}_{2} ; \mathrm{Qs}: 1.5 \times 10^{-7} ; \mathrm{V}: 0.1$ & [182] \\
\hline & & Ginger Rhizome & Terpenoids & $\mathrm{T}: 298 ; \mathrm{P}: 20 ; \mathrm{S}: \mathrm{CO}_{2} ; \mathrm{Qs}: 5.9 \times 10^{-5} ; \mathrm{V}: 0.232$ & [183] \\
\hline & $\begin{array}{l}\text { Substances when Using } \\
\text { Cosolvents }\end{array}$ & Buriti Pulp & $\begin{array}{l}\text { Carotenoids, } \\
\text { Tocopherols }\end{array}$ & $\mathrm{T}: 303 ; \mathrm{P}: 30 ; \mathrm{S}: \mathrm{CO}_{2} ; \mathrm{Qs}_{\mathrm{s}}: 4.3 \times 10^{-4} ; \mathrm{V}: 1$ & [184] \\
\hline & & Brazilian Cherry Pulp & Carotenoids & $\mathrm{T}: 333 ; \mathrm{P}: 25 ; \mathrm{S}: \mathrm{CO}_{2} ; \mathrm{Q}_{\mathrm{s}}: 6.8 \times 10^{-5} ; \mathrm{V}: 0.005$ & {$[185]$} \\
\hline \multirow{7}{*}{ PLE } & \multirow{3}{*}{$\begin{array}{l}\text { - Reduces Solvent Consumption } \\
\text {-Shortensthe Extraction Time } \\
\text {-Allows Simple Operation } \\
\text { - Uses Solvents Around the } \\
\text { Supercritical Region }\end{array}$} & Grape Peels & Anthocyanins & T: 313; P: 15; S: Methanol; V: 0.011 & [186] \\
\hline & & Spinach Leaves & Flavonoids & $\begin{array}{c}\mathrm{T}: 323 ; \mathrm{P}: 13.8 ; \mathrm{S}: \text { Ethanol + Water }(7: 3 \mathrm{v} / \mathrm{v}) \\
\mathrm{V}: 0.022\end{array}$ & [187] \\
\hline & & Jabuticaba Skins & Anthocyanins & T: 353; P: 5; S: Ethanol; V: 0.007; t: 9 & [7] \\
\hline & Supercritical Region & Oregano Leaves & Flavonoids & T: 323; P: 10; S: Water; V: 0.011 & [149] \\
\hline & 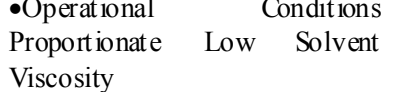 & Potato Peels & $\begin{array}{l}\text { Phenolic } \\
\text { Acids }\end{array}$ & $\begin{array}{c}\mathrm{T}: 433 ; \mathrm{P}: 6.9 ; \mathrm{S}: \text { Methanol+Water }(9: 1 \mathrm{v} / \mathrm{v}) \\
\text { V: } 0.011\end{array}$ & [188] \\
\hline & $\begin{array}{l}\text {-Extracts a Wide Range of } \\
\text { Antioxidant Compounds }\end{array}$ & Spearmint Leaves & Flavonoids & T: 363; P: 10; S: Methanol; t: 10 & [189] \\
\hline & $\begin{array}{l}\text {-Extracts Antioxidants Coming } \\
\text { from Hemicellulose } \\
\text { Depolymerization }\end{array}$ & Apple Bagasse & Polyphenols & $\begin{array}{c}\text { T: 374; P: } 10.3 ; \text { S: Ethanol + Water }(6: 4 \mathrm{v} / \mathrm{v}) \\
\text { V: } 0.022\end{array}$ & [190] \\
\hline \multirow{5}{*}{ MAE } & \multirow{5}{*}{$\begin{array}{l}\text {-Shortensthe Extraction Time } \\
\text { - Reduces Solvent Consumption } \\
\text {-Allows the Absence of Light } \\
\text { During the Extraction } \\
\text {-Presents the Capacity of } \\
\text { Processing Several Samples } \\
\text { Simultaneously } \\
\text {-Uses Raw Material that can be } \\
\text { Moist }\end{array}$} & Broccoli Staks & Phenols & $\begin{array}{c}\text { T: 344; S: Methanol + Water }(7.5: 2.5 \mathrm{v} / \mathrm{v}) ; \text { Pt: } \\
167 ; \mathrm{t}: 16\end{array}$ & [191] \\
\hline & & Grape Seeds & Phenols & $\begin{array}{c}\text { S: Ethanol+ Water }(3: 7 \mathrm{v} / \mathrm{v}) ; \mathrm{V}: 0.25 ; \mathrm{Pt}: 121 ; \\
\text { t: } 6\end{array}$ & [192] \\
\hline & & Cumin Leaves & Phenols & $\begin{array}{c}\mathrm{T}: 323 ; \mathrm{S}: \text { Ethanol }+ \text { Water }(5: 5 \mathrm{v} / \mathrm{v}) ; \mathrm{Pt}: 200 ; \mathrm{t}: \\
18\end{array}$ & [193] \\
\hline & & Whole Tomatoes & Polyphenols & 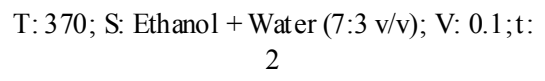 & {$[101]$} \\
\hline & & Peanut Skins & Polyphenols & $\begin{array}{c}\text { S: Methanol +Water }(3: 7 \mathrm{v} / \mathrm{v}) ; \mathrm{V}: 0.1 ; \mathrm{Pt}: 855 ; \\
\text { t: } 0.5\end{array}$ & {$[157]$} \\
\hline \multirow{5}{*}{ UAE } & \multirow{5}{*}{$\begin{array}{l}\text {-Shows Low Cost } \\
\text {-Exhibits Low Degradation of } \\
\text { Phytochemicals } \\
\text {-Shortens the Extraction Time } \\
\text { - Reduces Solvent Consumption } \\
\text {-Uses Simple Equipment }\end{array}$} & Soybean Grains & Isoflavones & T: 333; S: Ethanol+Water $(5: 5 \mathrm{v} / \mathrm{v}) ; \mathrm{t}: 10$ & [110] \\
\hline & & PomegranatePeels & Polyphenols & $\mathrm{T}: 333$; S: Ethanol + Water $(7: 3 \mathrm{v} / \mathrm{v}) ; \mathrm{t}: 30$ & [194] \\
\hline & & Marjoram Leaves & Polyphenols & T: 298; S: Water; V: $0.05 ; \mathrm{t}: 15$ & [195] \\
\hline & & Star Fruits & Phenols & T:298; S: Methanol; t: 30 & [196] \\
\hline & & Whole Acerola & Phenols & $\mathrm{T}: 323 ; \mathrm{S}:$ Water; V: $0.1 ; \mathrm{t}: 6$ & [197] \\
\hline \multicolumn{2}{|c|}{ * GRAS: Generally Recognized As Safe } & S: Solvent & & Qs: Solvent Flow Rate (kg/s) & \\
\hline \multicolumn{2}{|c|}{$\mathrm{T}$ : Temperature $(\mathrm{K})$} & $\mathrm{t}$ : Extraction Tim & nin) & V: Extractor Volume (L) & \\
\hline \multicolumn{2}{|c|}{ P: Pressure (MPa) } & Pt: Microwave Po & er $(\mathrm{W})$ & & \\
\hline
\end{tabular}

The lowest values of $\mathrm{IC}_{50}$ were found for extracts obtained from rice dye (Buddleia officinalis) $\left(3.1 \mu \mathrm{g} / \mathrm{cm}^{3}\right)$, rosemary (Rosmarinus officinalis) $\left(12.8 \mu \mathrm{g} / \mathrm{cm}^{3}\right.$ ), pomegranate (Punica granatum $)\left(14.5 \mu \mathrm{g} / \mathrm{cm}^{3}\right)$ andpeanut (Arachis hypogaea) $\left(14.9 \mu \mathrm{g} / \mathrm{cm}^{3}\right)$.

In summary, the antioxidant capacity is a function of process conditions which are related to the selected extraction technique. Process parameters of extraction influence the concentration of target compounds in the extract. The solvent characteristics, the extraction time and the temperature interfere in the selectivity of compounds and in the antio xidant properties of the extract. Furthermore, the origin of the raw material employed is the most influence in the antioxidant power. 
Almeidaet al.[122] obtained mint essential oil by SFE with $\mathrm{CO}_{2}$. The highest yield $(2.38 \%, \mathrm{w} / \mathrm{w})$ was obtained at 30 $\mathrm{MPa}$ and $323 \mathrm{~K}$. The $\mathrm{IC}_{50}$ in SFE extracts obtained without using cosolvent was $>250 \mu \mathrm{g} / \mathrm{cm}^{3}$. However,the $\mathrm{IC}_{50}$ in SFE extracts obtained using $20 \%(\mathrm{w} / \mathrm{w})$ of ethanol was 43.3 $\mu \mathrm{g} / \mathrm{cm}^{3}$. So, the SFE with cosolvent is an efficient method for obtaining antioxidant co mpounds fro $\mathrm{m}$ mint (Mentha spicata L.), as carvone, cineol and pulegone. Nevertheless, the SFE process without cosolvent is not capable of recovering caffeine and phenols from coffee (Coffea arabica). Andradeet al.[96] reached an $\mathrm{IC}_{50}$ of $1706 \mu \mathrm{g} / \mathrm{cm}^{3}$ using SFE
$\left(\mathrm{CO}_{2} / 20 \mathrm{MPa} / 313 \mathrm{~K}\right)$, while the $\mathrm{IC}_{50}$ was $235 \mu \mathrm{g} / \mathrm{cm}^{3}$ using UAE with ethanol as solvent, indicating UAE as a suitable technique for obtaining caffeine and phenols from coffee.MAE has been reported as an adequate technique for obtaining phenols with antioxidant properties from pomegranate (Punica granatum)[156] and phenolic diterpenes from rosemary (Rosmarinus officinalis)[154]. PLE was used for extracting major catechins from green tea, presenting advantages such as shorter extraction time and lower energy consumption[198]

Table 4. Antioxidant Capacit ies of Bioactive Compounds Extracted from Botanic Matrices Applying Different Extraction Techniques

\begin{tabular}{|c|c|c|c|c|c|c|}
\hline Raw Mate rial & Raw Mate rial Part & $\begin{array}{l}\text { Inhibition } \\
\text { Compounds }\end{array}$ & Method & Solvent & $\begin{array}{l}\mathrm{IC}_{50} \\
\left(\mu \mathrm{gg} \cdot \mathrm{cm}^{-3}\right)^{*}\end{array}$ & $\begin{array}{l}\text { Refer } \\
\text { ence }\end{array}$ \\
\hline \multirow{5}{*}{ Rosemary(Rosmarinus officinalis) } & \multirow{2}{*}{ Whole Fresh Leaves } & \multirow{4}{*}{$\begin{array}{l}\text { Carnosic and } \\
\text { Rosmarinic Acids }\end{array}$} & MAE & \multirow{4}{*}{ Water } & 47.0 & \multirow{4}{*}{ [154] } \\
\hline & & & UAE & & 86 & \\
\hline & Deoiled and Milled & & MAE & & 22.8 & \\
\hline & Leaves & & UAE & & 23.6 & \\
\hline & Leaves & Carnosic Acid & SFE & $\mathrm{CO}_{2}$ & 15.3 & [89] \\
\hline Coffee (Coffea arabica) & Ground & Caffeine and Phenols & UAE & $\mathrm{CO}_{2}+$ Ethanol & 235.1 & {$[96]$} \\
\hline \multirow{2}{*}{$\begin{array}{l}\text { Daylily (Hemerocallis disticha) } \\
\text { Mint (Mentha spicata L.) }\end{array}$} & Flowers & Lutein and Zeaxant in & \multirow{2}{*}{ SFE } & $\mathrm{CO}_{2}$ & 12.7 & [199] \\
\hline & Leaves & Carvone and Cineol & & $\mathrm{CO}_{2}+$ Ethanol & 43.3 & [122] \\
\hline (Lepidium apetalum) & & NI & SFE & $\mathrm{CO}_{2}$ & $1.0 \times 10^{3}$ & [200] \\
\hline $\begin{array}{l}\text { Sea Buckthorn (Hippophae } \\
\text { rhamnoides) }\end{array}$ & Seeds & Flavonoids & MAE & $\mathrm{SF}$ & 710.0 & {$[102]$} \\
\hline Tea (Camellia sinensis L.) & & NI & SFE & $\mathrm{CO}_{2}$ & $35.8 \times 10^{3}$ & [124] \\
\hline \multirow{3}{*}{ Mengkudu (Morinda citrifolia L.) } & \multirow{3}{*}{ Leaves } & \multirow{3}{*}{ Phenols } & UAE & Ethanol & 920.0 & \multirow{3}{*}{ [201] } \\
\hline & & & SFE & $\mathrm{CO}_{2}+$ Ethanol & $2.5 \times 10^{3}$ & \\
\hline & & & MAE & Ethanol & $2.1 \times 10^{3}$ & \\
\hline \multirow{2}{*}{ Orange (Citrus sinensis L.) } & \multirow{2}{*}{ Bagasse } & \multirow{2}{*}{ Phenolic Acids } & UAE & Ethyl Acetate & 434 & \multirow{2}{*}{ [126] } \\
\hline & & & SFE & $\mathrm{CO}_{2}+$ Ethanol & 403 & \\
\hline Saramjunamu (Sapium japonicum) & Leaves & Phenols & PLE & Ethanol + Water & 109.0 & [202] \\
\hline Mangosteen (Garcinia mangostana) & Fruits & Xanthones & \multirow{4}{*}{ SFE } & $\mathrm{CO}_{2}+$ Ethanol & 41.8 & {$[98]$} \\
\hline Indian-mulberry (Morinda citrifolia) & Stem & Polyphenols & & $\mathrm{CO}_{2}$ & $6.9 \times 10^{3}$ & {$[87]$} \\
\hline Patrinia (Patrinia villosa) & NI & Terpenoids & & $\mathrm{CO}_{2}+$ Methanol & 32.0 & [203] \\
\hline Rosemary (Rosm arinus officinalis) & Leaves & Phenolic Diterpenes & & $\mathrm{CO}_{2}$ & 12.8 & [204] \\
\hline $\begin{array}{l}\text { Black Chokeberry } \quad \text { (Aronia } \\
\text { melanocarpa) }\end{array}$ & Seeds & Polyphenols & UAE & Ethanol + Water & 200.0 & {$[166]$} \\
\hline Onion (Allium cepa) & Bulb & Quercet in & MAE & $\mathrm{SF}$ & $17.1 \times 10^{3}$ & [155] \\
\hline \multirow{2}{*}{ Leek (Allium porrum L.) } & Stem & \multirow{2}{*}{ Phenols } & \multirow{2}{*}{ UAE } & \multirow{2}{*}{ Ethanol } & 61.1 & \multirow{2}{*}[171]{} \\
\hline & Leaves & & & & 98.9 & \\
\hline Wormwood (Artemisia campestris) & \multirow{2}{*}{ AerialParts } & \multirow{2}{*}{ Flavonoids } & \multirow{2}{*}{ UAE } & \multirow{2}{*}{ Methanol } & 20.6 & \multirow{2}{*}[205]{} \\
\hline Mugwort (Artemisia vulgaris) & & & & & 26.5 & \\
\hline Lemon Balm (Melissa officinalis L.) & Leaves & Phenols & PLE & \multirow{2}{*}{ Ethanol } & 134.2 & [206] \\
\hline Peanut (Arachis hypogaea) & Bark & Flavonoids & $\mathrm{UAE}$ & & 14.9 & [104] \\
\hline Onion (Allium cepa) & Bulb & Quercet in & & $\mathrm{SF}$ & $7.0 \times 10^{3}$ & [155] \\
\hline Pomegranate (Punica granatum) & Peel & Phenols & MAE & Water & 14.5 & {$[156]$} \\
\hline Rice Dye (Buddleia officinalis) & NI & Lut eolin & & Ethanol & 3.1 & [207] \\
\hline
\end{tabular}




\section{Conclusions}

Obtaining extracts from botanic matrices usingnovel extr action techniques is increasing, andscientific investigations are progressively focusingon the natural antioxidants which are present in these extracts.Antioxidants have been receiving great attention because they bring benefits to the health and food fields. In this overview, the suitability of using each novel technique for obtaining different antioxidant phytochemicals, based on target compound characteristics, was emphasized.

\section{ACKNOWLEDGMENTS}

The authors thank CAPES, CNPq and FAPESP for the financial support. Moyses N. Moraes thanks CAPES and Giovani L. Zabot thanks FAPESP (2011/23665-2) for the Ph.D. assistantships. Juliana M. Prado thanks FAPESP (2010/08684-8) for the postdoctoral fellowship.

\section{REFERENCES}

[1] John Shi, Functional Food Ingredients and Nutraceuticals, CRC/Taylor \& Francis, Boca Raton (Fla.), 2007.

[2] Z. Djuric, R. K. Severson, I. Kato, "Association of Dietary Quercetin With Reduced Risk of Proximal Colon Cancer", Nutrition and Cancer, vol.64, no.3, pp.351-360, 2012.

[3] P. Karna, S. Chagani, S. R. Gundala, P. C. G. Rida, G. Asif, V. Sharma, M. V. Gupta, R. Aneja, "Benefits of whole Ginger Extract in Prostate Cancer", British Journal of Nutrition, vol.107, no.4, pp.473-484, 2012.

[4] B. J. Xu, S. K. C. Chang, "Comparative Study on Antiproliferation Properties and Cellular Antioxidant Activities of Commonly Consumed Food Legumes A gainst Nine Human Cancer Cell Lines", Food Chemistry, vol.134, no.3, pp.1287-1296, 2012.

[5] B. Halliwell, "How to Characterize a Biological Antioxidant", Free radical research communications, vol.9, no.1, pp.1-32, 1990.

[6] H. J. Bae, G. K. Jayaprakasha, J. Jifon, B. S. Patil, "Variation of Antioxidant Activity and the Levels of Bioactive Compounds in Lipophilic and Hydrophilic Extracts from Hot Pepper (Capsicum spp.) Cultivars", Food Chemistry, vol.134, no.4, pp.1912-1918, 2012.

[7] Fereidoon Shahidi, Marian Naczk, Phenolics in Food and Nutraceuticals, CRC Press, Boca Raton, 2003.

[8] W. Bors, C. Michel, K. Stettmaier, "Electron Paramagnetic Resonance Studies of Radical Species of Proanthocyanidins and Gallate Esters", Archives of Biochemistry and Biophysics, vol.374, no.2, pp.347-355, 2000.

[9] M. Monica Giusti, Pu Jing, Natural Pigments of Berries: Functionality and Application, In. Berry fruit: value-added products for health promotion, Y Zhao, pp.105-146, CRC Press, Boca Raton, 2007.
[10] H. Van Praag, M. J. Lucero, G. W. Yeo, K. Stecker, N. Heivand, C. Zhao, E. Yip, M. Afanador, H. Schroeter, J. Hammerstone, F. H. Gage, "Plant-Derived Flavanol (-)Epicatechin Enhances Angiogenesis and Retention of Spatial Memory in Mice", Journal of Neuroscience, vol.27, no.22, pp.5869-5878, 2007.

[11] T. M. Spormann, F. W. Albert, T. Rath, H. Dietrich, F. Will, J. P. Stockis, G. Eisenbrand, C. Janzowski, "Anthocy anin/ Polyphenolic-Rich Fruit Juice Reduces Oxidative Cell Damage in an Intervention Study with Patients on Hemodialysis", Cancer Epidemiology Biomarkers and Prevention, vol.17, no.12, pp.3372-3380, 2008.

[12] M. Kamiyama, T. Shibamoto, "Flavonoids with Potent Antioxidant Activity Found in Young Green Barley Leaves", Journal of Agricultural and Food Chemistry, vol.60, no.25, pp.6260-6267, 2012.

[13] P. Thangavel, R. Muthu, M. Vaiyapuri, "Antioxidant Potential of Naringin - a Dietary Flavonoid - in N-Nitrosodiethy lamine Induced Rat Liver Carcinogenesis", Biomedicine and Preventive Nutrition, In Press, 2012,

[14] J. Boateng, M. Verghese, "Protective Effects of the Phenolic Extracts of Fruits Against Oxidative Stress in Human Lung Cells", International Journal of Pharmacology, vol.8, no.3, pp.152-160, 2012.

[15] J. A. Joseph, B. Shukitt-Hale, G. J. Brewer, K. A. Weikel, W. Kalt, D. R. Fisher, "Differential Protection Among Fractionated Blueberry Polyphenolic Families Against DA-, A $342-$ and LPS-Induced Decrements in $\mathrm{Ca} 2+$ Buffering in Primary Hippocampal Cells", Journal of Agricultural and Food Chemistry, vol.58, no.14, pp.8196-8204, 2010.

[16] R. H. Mohamad, A. M. El-Bastawesy, M. G. Abdel-Monem, A. M. Noor, H. A. R. Al-Mehdar, S. M. Sharawy, M. M. El-Merzabani, "Antioxidant and Anticarcinogenic Effects of Methanolic Extract and Volatile oil of Fennel Seeds (Foeniculum vulgare)", Journal of Medicinal Food, vol.14, no.9, pp.986-1001, 2011.

[17] A. B. Hsouna, M. Saoudi, M. Trigui, K. Jamoussi, T. Boudawara, S. Jaoua, A. E. Feki, "Characterization of Bioactive Compounds and Ameliorative Effects of Ceratonia siliqua Leaf Extract Against CCl4 Induced Hepatic Oxidative Damage and Renal Failure in Rats", Food and Chemical Toxicology, vol.49, no.12, pp.3183-3191, 2011.

[18] M. Nishizawa, T. Hara, T. Miura, S. Fujita, E. Yoshigai, H. Ue, Y. Hayashi, A. H. Kwon, T. Okumura, T. Isaka, "Supplementation with a Flavanol-Rich Lychee Fruit Extract Influences the Inflammatory Status of Young Athletes", Phytotherapy Research, vol.25, no.10, pp.1486-1493, 2011.

[19] M. N. Clifford, "Chlorogenic Acids and Other Cinnamates Nature, Occurrence and Dietary Burden", Journal of the Science of Food and Agriculture, vol.79, no.3, pp.362-372, 1999.

[20] C. T. Yeh, G. C. Yen, "Induction of Hepatic Antioxidant Enzymes by Phenolic Acids in Rats is Accompanied by Increased Levels of Multidrug Resistance-Associated Protein 3 mRNA Expression", Journal of Nutrition, vol.136, no.1, pp.11-15, 2006.

[21] M. Watabe, K. Hishikawa, A. Takayanagi, N. Shimizu, T. Nakaki, "Caffeic Acid Phenethyl Ester Induces Apoptosis by Inhibition of NFKB and Activation of Fas in Human Breast 
Cancer MCF-7 Cells", Journal of Biological Chemistry, vol.279, no.7, pp.6017-6026, 2004.

[22] T. Pluemsamran, T. Onkoksoong, U. Panich, "Caffeic Acid and Ferulic Acid Inhibit UVA-Induced Matrix Metalloproteinase-1 Through Regulation of Antioxidant Defense System in Keratinocyte HaCaT Cells", Photochemistry and Photobiology, vol.88, no.4, pp.961-968, 2012.

[23] X. F. Lin, W. Min, D. Luo, "Anticarcinogenic Effect of Ferulic Acid on Ultraviolet-B Irradiated Human Keratinocy te HaCaT Cells", Journal of Medicinal Plants Research, vol.4, no.16, pp.1686-1694, 2010.

[24] Charles Sell, Chemistry Royal Society of, A fragrant Introduction to Terpenoid Chemistry, Royal Society of Chemistry, Cambridge, 2003.

[25] J. V. Rossoni Jr, G. R. Araújo, B. D. C. Padua, M. M. Chaves, M. L. Pedrosa, M. E. Silva, D. C. Costa, "Annato Extract and $\beta$-Carotene Modulate the Production of Reactive Oxygen Species/Nitric Oxide in Neutrophils from Diabetic Rats", Journal of Clinical Biochemistry and Nutrition, vol.50, no.3, pp.177-183, 2012.

[26] J. D. Tibodeau, C. R. Isham, K. C. Bible, "Annatto Constituent Cis-Bixin Has Selective Antimyeloma Effects Mediated by Oxidative Stress and Associated with Inhibition of Thioredoxin and Thioredoxin Reductase", Antioxidants and Redox Signaling, vol.13, no.7, pp.987-997, 2010.

[27] P. Palozza, R. Simone, A. Catalano, M. Russo, V. Böhm, "Lycopene Modulation of Molecular Targets Affected by Smoking Exposure", Current Cancer Drug Targets, vol.12, no.6, pp.640-657, 2012

[28] R. E. Simone, M. Russo, A. Catalano, G. Monego, K. Froehlich, V. Boehm, P. Palozza, "Lycopene Inhibits NF-KB-Mediated IL-8 Expression and Changes Redox and PPAR $\gamma$ Signalling in Cigarette Smoke-Stimulated Macrophages", PLoS ONE, vol.6, no.5, pp.1-11, 2011.

[29] M. Kang, K. S. Park, J. Y. Seo, H. Kim, "Lycopene Inhibits IL-6 Expression in Cerulein-Stimulated Pancreatic Acinar Cells", Genes and Nutrition, vol.6, no.2, pp.117-123, 2011.

[30] V. A. Kirsh, R. B. Hayes, S. T. Mayne, N. Chatterjee, A. F. Subar, L. B. Dixon, D. Albanes, G. L. Andriole, D. A. Urban, U. Peters, Pclo Trial, "Supplemental and Dietary Vitamin E, Beta-Carotene, and Vitamin C Intakes and Prostate Cancer Risk", Journal of the National Cancer Institute, vol.98, no.4, pp.245-254, 2006.

[31] Y. Kim, J. H. Seo, H. Kim, "beta-Carotene and Lutein Inhibit Hydrogen Peroxide-Induced Activation of NF-Kappa B and IL-8 Expression in Gastric Epithelial AGS Cells", Journal of Nutritional Science and Vitaminology, vol.57, no.3, pp.216-223, 2011.

[32] Y. Sun, A. Ma, Y. Li, X. Han, Q. Wang, H. Liang, "Vitamin E Supplementation Protects Erythrocyte Membranes from Oxidative Stress in Healthy Chinese Middle-Aged and Elderly People", Nutrition Research, vol.32, no.5,pp.328-334, 2012.

[33] J. Wang, P. Sun, Y. Bao, B. Dou, D. Song, Y. Li, "Vitamin E Renders Protection to PC12 Cells Against Oxidative Damage and Apoptosis Induced by Single-Walled Carbon Nanotubes", Toxicology in Vitro, vol.26, no.1, pp.32-41, 2012.
[34] G. R. Sajitha, R. Jose, A. Andrews, K. G. Ajantha, P. Augustine, K. T. Augusti, "Garlic Oil and Vitamin e Prevent the Adverse Effects of Lead Acetate and Ethanol Separately as well as in Combination in the Drinking Water of Rats", Indian Journal of Clinical Biochemistry, vol.25, no.3, pp. $280-288,2010$.

[35] I. M. Lee, N. R. Cook, J. M. Gaziano, D. Gordon, P. M. Ridker, J. E. Manson, C. H. Hennekens, J. E. Buring, "Vitamin E in the Primary Prevention of Cardiovascular Disease and Cancer. The Women's Health Study: A Randomized Controlled Trial", Journal of the American Medical Association, vol.294, no.1, pp.56-65, 2005.

[36] S. Rahman, K. Bhatia, A. Q. Khan, M. Kaur, F. Ahmad, H. Rashid, M. Athar, F. Islam, S. Raisuddin, "Topically Applied Vitamin E Prevents Massive Cutaneous Inflammatory and Oxidative Stress Responses Induced by Double Application of 12-O-Tetradecanoy lphorbol-13-Acetate (TPA) in Mice", Chemico-Biological Interactions, vol.172, no.3, pp.195-205, 2008.

[37] D. Patacsil, S. Osayi, A. T. Tran, F. Saenz, L. Yimer, A. N. Shajahan, P. C. Gokhale, M. Verma, R. Clarke, S. C. Chauhan, D. Kumar, "Vitamin E Succinate Inhibits Survivin and Induces Apoptosis in Pancreatic Cancer Cells", Genes and Nutrition, vol.7, no.1, pp.83-89, 2012.

[38] T. Miyazawa, K. Nakagawa, P. Sookwong, "Health Benefits of Vitamin E in Grains, Cereals and Green Vegetables", Trends in Food Science and Technology, vol.22, no.12, pp.651-654, 2011.

[39] G. L. Hostetler, K. M. Riedl, S. J. Schwartz, "Endogenous Enzymes, Heat, and pH Affect Flavone Profiles in Parsley (Petroselinum crispum var. neapolitanum) and Celery (Apium graveolens) during Juice Processing", Journal of Agricultural and Food Chemistry, vol.60, no.1, pp.202-208, 2012.

[40] A. Gironés-Vilaplana, P. Valentao, P. B. Andrade, F. Ferreres, D. A. Moreno, C. García-Viguera, "Phy tochemical Profile of a Blend of Black Chokeberry and Lemon Juice with Cholinesterase Inhibitory Effect and Antioxidant Potential", Food Chemistry, vol.134, no.4,pp.2090-2096, 2012.

[41] D. D. Wang, J. Wang, X. H. Huang, Y. Tu, K. Y. Ni, "Identification of Polymethoxylated Flavones from Green Tangerine Peel (Pericarpium Citri Reticulatae Viride) by Chromatographic and Spectroscopic Techniques", Journal of Pharmaceutical and Biomedical Analysis, vol.44, no.1, pp.63-69, 2007.

[42] S. M. Li, T. Lambros, Z. Y. Wang, R. Goodnow, C. T. Ho, "Efficient and Scalable Method in Isolation of Polymethoxy flavones from Orange Peel Extract by Supercritical Fluid Chromatography", Journal of Chromatography B, vol.846, no.1-2, pp.291-297, 2007.

[43] M. Skerget, P. Kotnik, M. Hadolin, H. R. Hras, M. Simonic, Z. Knez, "Phenols, Proanthocyanidins, Flavones and Flavonols in Some Plant Materials and their Antioxidant Activities", Food Chemistry, vol.89, no.2, pp.191-198, 2005.

[44] N. S. Bai, K. He, M. Roller, C. S. Lai, X. Shao, M. H. Pan, C. T. Ho, "Flavonoids and Phenolic Compounds from Rosmarinus officinalis", Journal of Agricultural and Food Chemistry, vol.58, no.9, pp.5363-5367, 2010.

[45] A. Marin, F. Ferreres, F. A. Tomás-Barberán, M. I. Gil, 
"Characterization and Quantitation of Antioxidant Constituents of Sweet Pepper (Capsicum annuum L.)", Journal of Agricultural and Food Chemistry, vol.52, no.12, pp.3861-3869, 2004.

[46] C. Caristi, E. Bellocco, V. Panzera, G. Toscano, R. Vadala, U. Leuzzi, "Flavonoids Detection by HPLC-DAD-MS-MS in Lemon Juices from Sicilian Cultivars", Journal of Agricultural and Food Chemistry, vol.51, no.12, pp. 3528 3534, 2003.

[47] A. Vallverdu-Queralt, O. Jauregui, G. Di Lecce, C. Andres-Lacueva, R. M. Lamuela-Raventos, "Screening of the Polyphenol Content of Tomato-Based Products Through Accurate-Mass Spectrometry (HPLC-ESI-QTOF)", Food Chemistry, vol.129, no.3, pp.877-883, 2011.

[48] M. Bimakr, R. L. A. Rahman, F. S. Taip, A. Ganjloo, L. M. Salleh, J. Selamat, A. Hamid, I. S. M. Zaidul, "Comparison of Different Extraction Methods for the Extraction of Major Bioactive Flavonoid Compounds from Spearmint (Mentha spicata L.) Leaves", Food and Bioproducts Processing, vol.89, pp.67-72, 2011.

[49] S. M. S. Sawalha, D. Arraez-Roman, A. Segura-Carretero, A. Fernandez-Gutierrez, "Quantification of Main Phenolic Compounds in Sweet and Bitter Orange Peel Using CE-MS/MS", Food Chemistry, vol.116, no.2, pp.567-574, 2009.

[50] W. Stuetz, T. Prapamontol, S. Hon gsibsong, H. K. Biesalski, "Polymethoxylated Flavones, Flavanone Glycosides, Carotenoids, and Antioxidants in Different Cultivation Types of Tangerines (Citrus reticulata Blanco cv. Sainampueng) from Northern Thailand", Journal of A gricultural and Food Chemistry, vol.58, no.10, pp.6069-6074, 2010.

[51] J. R. Patil, K. N. C.Murthy, G. K. Jay aprakasha, M. B. Chetti, B. S. Patil, "Bioactive Compounds from Mexican Lime (Citrus aurantifolia) Juice Induce Apoptosis in Human Pancreatic Cells", Journal of Agricultural and Food Chemistry, vol.57, no.22, pp.10933-10942, 2009.

[52] A. Raal, A. Orav, T. Püssa, C. Valner, B. Malmiste, E. Arak, "Content of Essential Oil, Terpenoids and Polyphenols in Commercial Chamomile (Chamomilla recutita L. Rauschert) Teas From Different Countries", Food Chemistry, vol.131, no.2, pp.632-638, 2012.

[53] M. A. Rostagno, N. Manchon, M. D'Arrigo, E. Guillamon, A. Villares, A. Garcia-Lafuente, A. Ramos, J. A. Martinez, "Fast and Simultaneous Determination of Phenolic Compounds and Caffeine in Teas, Mate, Instant Coffee, Soft Drink and Energetic Drink by High-Performance Liquid Chromatography Using a Fused-Core Column", Analytica Chimica Acta, vol.685, no.2, pp.204-211, 2011.

[54] E. S. de Brito, M. C. Pessanha de Araújo, L. Z. Lin, J. Harnly, "Determination of the Flavonoid Components of Cashew Apple (Anacardium occidentale) by LC-DAD-ESI/MS", Food Chemistry, vol.105, no.3, pp.1112-1118, 2007.

[55] S. F. Reis, D. K. Rai, N. Abu-Ghannam, "Water at Room Temperature as a Solvent for the Extraction of Apple Pomace Phenolic Compounds", Food Chemistry, vol.135, no.3, pp.1991-1998, 2012.

[56] K. Aaby, S. Mazur, A. Nes, G. Skrede, "Phenolic Compounds in Strawberry (Fragaria $\mathrm{x}$ ananassa Duch.) Fruits: Composition in 27 Cultivars and Changes During Ripening",
Food Chemistry, vol.132, no.1,pp.86-97, 2012.

[57] M. Dehkharghanian, H. Adenier, M. A. Vijayalakshmi, "Study of Flavonoids in Aqueous Spinach Extract Using Positive Electrospray Ionisation Tandem Quadrupole Mass Spectrometry", Food Chemistry, vol.121, no.3, pp.863-870, 2010.

[58] R. Perestrelo, Y. Lu, S. A. O. Santos, A. J. D. Silvestre, C. P. Neto, J. S. Câmara, S. M. Rocha, "Phenolic Profile of Sercial and Tinta Negra Vitis vinifera L. Grape Skins by HPLC-DAD-ESI-MS n: Novel Phenolic Compounds in Vitis vinifera L. grape", Food Chemistry, vol.135, no.1,pp.94-104, 2012.

[59] R. Bobinait, P. Viškelis, P. R. Venskutonis, "Variation of Total Phenolics, Anthocyanins, Ellagic Acid and Radical Scavenging Capacity in Various Raspberry (Rubus spp.) Cultivars", Food Chemistry, vol.132, no.3, pp.1495-1501, 2012.

[60] I. Damar, A. Ekşi, "Antioxidant Capacity and Anthocyanin Profile of Sour Cherry (Prunus cerasus L.) Juice", Food Chemistry, vol.135, no.4,pp.2910-2914, 2012.

[61] Diego T. Santos, Priscilla C. Veggi, M. Angela A. Meireles, "Extraction of Antioxidant Compounds from Jabuticaba (Myrciaria cauliflora) Skins: Yield, Composition and Economical Evaluation", Journal of Food Engineering, vol.101, no.1, pp.23-31, 2010.

[62] E. Sentandreu, J. L. Navarro, J. M. Sendra, "Identification of New Coloured Anthocyanin-Flavanol Adducts in Pressure-Extracted Pomegranate (Punica granatum L.) Juice by High-Performance Liquid Chromatography/Electrospray Ionization Mass Spectrometry", Food Analytical Methods, vol.5, no.4, pp.702-709, 2012.

[63] Y. Wang, X. L. Chen, Y. M.Zhang, X. S. Chen, "Antioxidant Activities and Major Anthocyanins of Myrobalan Plum (Prunus cerasifera Ehrh.)", Journal of Food Science, vol.77, no.4, pp.C388-C393, 2012.

[64] M. J. Payne, W. J. Hurst, K. B. Miller, C. Rank, D. A. Stuart, "Impact of Fermentation, Drying, Roasting, and Dutch Processing on Epicatechin and Catechin Content of Cacao Beans and Cocoa Ingredients", Journal of Agricultural and Food Chemistry, vol.58, no.19, pp.10518-10527, 2010.

[65] A. K. Biswas, J. Sahoo, M. K. Chatli, "A simple UV-Vis Spectrophotometric Method for Determination of $\beta$-Carotene Content in Raw Carrot, Sweet Potato and Supplemented Chicken Meat Nuggets", LWT - Food Science and Technology, vol.44, no.8, pp.1809-1813, 2011.

[66] M. G. Dias, M. F. G. F. C. Camões, L. Oliveira, "Carotenoids in Traditional Portuguese Fruits and Vegetables", Food Chemistry, vol.113, no.3, pp.808-815, 2009.

[67] C. Kurz, R. Carle, A. Schieber, "HPLC-DAD-MSn Characterisation of Carotenoids from Apricots and Pumpkins for the Evaluation of Fruit Product Authenticity", Food Chemistry, vol.110, no.2, pp.522-530, 2008.

[68] L. E. Gayosso-García Sancho, E. M. Yahia, G. A. González-Aguilar, "Identification and Quantification of Phenols, Carotenoids, and Vitamin C from Papaya (Carica papaya L., cv. Maradol) Fruit Determined by HPLC-DAD-MSMS-ESI", Food Research International, vol.44, no.5, pp.1284-1291, 2011. 
[69] C. H. Azevedo - Meleiro, D. B. Rodriguez - Amaya, "Qualitative and Quantitative Differences in Carotenoid Composition Among Cucurbita moschata, Cucurbita maxima, and Cucurbita pepo", Journal of Agricultural and Food Chemistry, vol.55, no.10, pp.4027-4033, 2007.

[70] D. B. Rodriguez-Amaya, M. Kimura, H. T. Godoy, J. Amaya-Farfan, "Updated Brazilian Database on Food Carotenoids: Factors Affecting Carotenoid Composition", Journal of Food Composition and Analysis, vol.21, no.6, pp.445-463, 2008.

[71] H. Ashrafi, M. P. Kinkade, H. L. Merk, M. R. Foolad, "Identification of Novel Quantitative Trait Loci for Increased Lycopene Content and Other Fruit Quality Traits in a Tomato Recombinant Inbred Line Population", Molecular Breeding, vol.30, no.1, pp.549-567, 2012.

[72] R. M. Schweiggert, C. B. Steingass, A. Heller, P. Esquivel, R. Carle, "Characterization of Chromoplasts and Carotenoids of Red- and Yellow-Fleshed Papaya (Carica papaya L.)", Planta, vol.234, no.5, pp.1031-1044, 2011.

[73] I. Tlili, C. Hdider, M. S. Lenucci, I. Riadh, H. Jebari, G. Dalessandro, "Bioactive Compounds and Antioxidant Activit ies of Different Watermelon (Citrullus lanatus (Thunb.) Mansfeld) Cultivars as Affected by Fruit Sampling Area", Journal of Food Composition and Analysis, vol.24, no.3, pp.307-314, 2011.

[74] K. W. Kong, A. Ismail, "Lycopene Content and Lipophilic Antioxidant Capacity of By-Products from Psidium guajava Fruits Produced During Puree Production Industry", Food and Bioproducts Processing, vol.89, no.C1, pp.53-61, 2011.

[75] L. Del Moral, J. M. Fernandez-Martínez, B. Pérez-Vich, L. Velasco, "Expression of Modified Tocopherol Content and Profile in Sunflower Tissues", Journal of the Science of Food and Agriculture, vol.92, no.2, pp.351-357, 2012.

[76] J. Chun, J. Lee, R. R. Eitenmiller, "Vitamin E and Oxidative Stability During Storage of Raw and Dry Roasted Peanuts Packaged Under Air and Vacuum", Journal of Food Science, vol.70, no.4, pp.C292-C297, 2005.

[77] Y. Y. Lee, H. M. Park, C. K. Lee, S. L. Kim, T. Y. Hwang, M. S. Choi, Y. U. Kwon, W. H. Kim, S. J. Kim, S. C. Lee, Y. H. Kim, "Comparing Extraction Methods for the Determination of Tocopherols and Tocotrienols in Seeds and Germinating Seeds of Soybean Transformed with OsHGGT", Journal of Food Composition and Analysis, vol.27, no.1, pp.70-80, 2012.

[78] W. W. Ren, L. X. Zhao, Y. L. Wang, L. J. Cui, Y. L. Tang, X. F. Sun, K. X. Tang, "Overexpression of Homogentisate Phytyltransferase in Lettuce Results in Increased Content of Vitamin E", African Journal of Biotechnology, vol.10, no.64, pp.14046-14051, 2011.

[79] Z. W. Sheng, W. H. Ma, Z. Q. Jin, Y. Bi, Z. G. Sun, H. T. Dou, J. H. Gao, J. Y. Li, L. N. Han, "Investigation of Dietary Fiber, Protein, Vitamin E and Other Nutritional Compounds of Banana Flower of Two Cultivars Grown in China", African Journal of Biotechnology, vol.9, no.25, pp.3888-3895, 2010.

[80] L. Jakobek, M. Seruga, S. Voca, Z. Sindrak, N. Dobricevic, "Flavonol and Phenolic Acid Composition of Sweet Cherries (cv. Lapins) Produced on Six Different Vegetative Rootstocks", Scientia Horticulturae, vol.123, no.1, pp.23-28, 2009.
[81] N. J. Kang, K. W. Lee, B. J. Shin, S. K. Jung, M. K. Hwang, A. M. Bode, Y. S. Heo, H. J. Lee, Z. G. Dong, "Caffeic Acid, a Phenolic Phytochemical in Coffee, Directly Inhibits Fyn Kinase Activity and UVB-Induced COX-2 Expression", Carcinogen esis, vol.30, no.2, pp.321-330, 2009.

[82] R. Horax, N. Hettiarachchy, S. Islam, "Total Phenolic Contents and Phenolic Acid Constituents in 4 Varieties of Bitter Melons (Momordica charantia) and Antioxidant Activities of their Extracts", Journal of Food Science, vol.70, no.4, pp.C275-C280, 2005.

[83] Stanley T. Omaye, Food and Nutritional Toxicology, CRC Press, Boca Raton-FL, 2004.

[84] R. C. Lindenschmidt, A. F. Tryka, M. E. Goad, H. P. Witschi, "The Efffects of Dietary Butylated Hydroxy toluene on Liver and Colon-Tumor Development in Mice", Toxicology, vol.38, no.2, pp.151-160, 1986.

[85] K. Míková, The Regulation of Antioxidants in Food, Vol. 2, In. Food Chemical Safety, DH Watson, pp.267-283, CRC Press; Woodhead, Boca Raton, Fla.; Cambridge, 2002.

[86] Henry I. Castro-Vargas, Luis I. Rodríguez-Varela, Sandra R. S. Ferreira, Fabián Parada-Alfonso, "Extraction of Phenolic Fraction from Guava Seeds (Psidium guajava L.) Using Supercritical Carbon Dioxide and Co-Solvents", Journal of Supercritical Fluids, vol.51, no.3, pp.319-324, 2010.

[87] Chin-Hui Chen, Tsuey-Pin Lin, Yu-Ling Chung, Ching-Kuo Lee, Dong-Bor Yeh, Shih-Ying Chen, "Determination of Antioxidative Properties of Morinda citrifolia Using Near Supercritical Fluid Extraction", Journal of Food and Drug Analysis, vol.17, no.5, pp.333-341, 2009.

[88] Michelle Co, Amelie Fagerlund, Lars Engman, Kerstin Sunnerheim, Per J. R. Sjoberg, Charlotta Turner, "Extraction of Antioxidants from Spruce (Picea abies) Bark Using Eco-Friendly Solvents", Phytochemical Analysis, vol.23, no.1, pp.1-11, 2012.

[89] Gonzalo Vicente, Mônica R. García-Risco, Tiziana Fornari, Guillermo Reglero, "Sup ercritical Fractionation of Rosemary Extracts to Improve the Antioxidant Activity", Chemical Engineering \& Technology, vol.35, no.1, pp.176-182, 2012.

[90] H. H. Wijngaard, M. Ballay, N. Brunton, "The Optimisation of Extraction of Antioxidants from Potato Peel by Pressurised Liquids", Food Chemistry, vol.133, no.4, pp.1123-1130, 2012.

[91] Le Ying, Ping Xu, Shuangru Huang, Yuefei Wang, "Antioxidant Activity of Bioactive Compounds Extracted from Ampelopsis grossedentata Leaves by Optimized Supercritical Carbon Dioxide", Journal of Medicinal Plants Research, vol.5, no.17, pp.4373-4381, 2011.

[92] Hee-Ock Boo, Sung-Jin Hwang, Chun-Sik Bae, Su-Hyun Park, Buk-Gu Heo, Shela Gorinstein, "Extraction and Characterization of Some Natural Plant Pigments", Industrial Crops and Products, vol.40,pp.129-135, 2012.

[93] Monika A. Olszewska, Anna Presler, Piotr Michel, "Profiling of Phenolic Compounds and Antioxidant Activity of Dry Extracts from the Selected Sorbus Species", Molecules, vol.17, no.3, pp.3093-3113, 2012.

[94] Kanti Bhooshan Pandey, Syed Ibrahim Rizvi, "Plant Polyphenols as Dietary Antioxidants in Human Health and 
Disease", Oxidative Medicine and Cellular Longevity, vol.2, no.5, pp.270-278, 2009.

[95] F. Agostini, R. A. Bertussi, G. Agostini, A. C. Atti dos Santos, M. Rossato, R. Vanderlinde, "Supercritical Extraction from Vinification Residues: Fatty Acids, Alpha-Tocopherol, and Phenolic Compounds in the Oil Seeds from Different Varieties of Grape", The Scientific World Journal,, pp.1-9, 2012.

[96] Kátia S. Andrade, Ricardo T. Gonçalvez, Marcelo Maraschin, Rosa Maria Ribeiro-do-Valle, Julian Martínez, Sandra R. S. Ferreira, "Supercritical Fluid Extraction from Spent Coffee Grounds and Coffee Husks: Antioxidant Activity and Effect of Operational Variables on Extract Composition", Talanta, vol.88, pp.544-552, 2012.

[97] Claudia P. Passos, Rui M. Silva, Francisco A. Da Silva, Manuel A. Coimbra, Carlos M. Silva, "Supercritical Fluid Extraction of Grape Seed (Vitis vinifera L.) Oil. Effect of the Operating Conditions Upon Oil Composition and Antioxidant Capacity", Chemical Engineering Journal, vol.160, no.2, pp.634-640, 2010.

[98] A. S. Zarena, K. Udaya Sankar, "Supercritical Carbon Dioxide Extraction of Xanthones with Antioxidant Activity from Garcinia man gostana: Characterization by HPLC/ LCESI -MS", Journal of Supercritical Fluids, vol.49, no.3, pp.330-337, 2009.

[99] M. Cam, Y. Hisil, "Pressurised Water Extraction of Polyphenols from Pomegranate Peels", Food Chemistry, vol.123, no.3, pp.878-885, 2010 .

[100] S. Erdogan, B. Ates, G. Durmaz, I. Yilmaz, T. Seckin, "Pressurized Liquid Extraction of Phenolic Compounds from Anatolia Propolis and their Radical Scavenging Capacities", Food and Chemical Toxicology, vol.49, no.7, pp.1592-1597, 2011.

[101] Hongy an Li, Zeyuan Deng, Tao Wu, Ronghua Liu, Steven Loewen, Rong Tsao, "Microwave-Assisted Extraction of Phenolics with Maximal Antioxid ant Activities in Tomatoes", Food Chemistry, vol.130, no.4, pp.928-936, 2012.

[102] Sandrine Perino-Issartier, Huma Zill e, Mary line Abert-Vian, Farid Chemat, "Solvent Free Microwave-Assisted Extraction of Antioxidants from Sea Buckthorn (Hippophae rhamnoides) Food By-Products", Food and Bioprocess Technology, vol.4, no.6, pp.1020-1028, 2011.

[103] Meric Simsek, Gulum Sumnu, Serpil Sahin, "Microwave Assisted Extraction of Phenolic Compounds from Sour Cherry Pomace", Separation Science and Technology, vol.47, no.8, pp.1248-1254, 2012.

[104] Jie Bi, Qingli Yang, Jie Sun, Jian Chen, Juan Zhang, "Study on Ultrasonic Extraction Technology and Oxidation Resistance of Total Flavonoids from Peanut Hull", Food Science and Technology Research, vol.17, no.3, pp.187-198, 2011.

[105] Kashif Ghafoor, Teng Hui, Yong Hee Choi, "Optimization of Ultrasonic-Assisted Extraction of Total Anthocyanins from Grape Peel Using Response Surface Methodology", Journal of Food Biochemistry, vol.35, no.3, pp.735-746, 2011.

[106] E. Vági, B. Simándi, K. P. Vásárhely iné, H. Daood, A. Kéry, F. Doleschall, B. Nagy, "Supercritical Carbon Dioxide Extraction of Carotenoids, Tocopherols and Sitosterols from
Industrial Tomato By-Products", Journal of Supercritical Fluids, vol.40, no.2, pp.218-226, 2007.

[107] J. K. Monrad, L. R. Howard, J. W. King, K. Srinivas, A. Mauromoustakos, "Subcritical Solvent Extraction of Anthocyanins from Dried Red Grape Pomace", Journal of Agricultural and Food Chemistry, vol.58, no.5,pp.2862-2868, 2010.

[108] B. Aliakbarian, A. Fathi, P. Perego, F. Dehghani, "Extraction of Antioxidants from Winery Wastes Using Subcritical Water", Journal of Supercritical Fluids, vol.65, pp.18-24, 2012.

[109] Thaís M. Takeuchi, Camila G. Pereira, Mara E. M. Braga, Mário R. Maróstica, Patrícia F. Leal, Maria Angela A. Meireles, Low-Pressure Solvent Extraction (Solid-Liquid Extraction, Microwave Assisted and Ultrassound Assisted) from Condimentary Plants, In. Extracting bioactive compounds for food products: theory and applications, MAA Meireles, pp.137-218, CRC Press, Boca Raton, 2009.

[110] M. A. Rostagno, M. Palma, C. G. Barroso, "Ultrasound Assisted Extraction of Soy Isoflavones", Journal of Chromatography A, vol.1012, no.2,pp.119-128, 2003.

[111]K. Zosel, Process for Recovering Caffeine, US 3806619 , Oberhausen/Rhein land (DE), 1974.

[112] K. Zosel, Process for the Decaffeination of Coffee, US 4247570, Oberhausen (DE), 1981

[113]D. Chou, Y. Wu, L. Wang, Preparing Carotenoid Microcapsules with a Controllable Isomeric Ratio, Comprises Separating Carotenoids in Chromatographic Column, Washing with a Mobile Phase, and Adding Stationary Phase after Absorbing Isomer into a High Pressure Kettle, CN101879428-A, Kajang (MY), 2012.

[114] C. Y. May, M. A. Ngan, Y. Basiron, D. Y. Basiron, A. N.Ma, Y. M. Choo, D. D. Y. Basiron, Isolation of Vitamin E isomers from Tocols Useful as a Nutritional Antioxidant Involves the use of the Supercritical Fluid in the Adsorption/Desorption Chromatography, EP1122250-A, Kajang (MY), 2003.

[115] J. Chen, K. Yang, S. Chen, T. Adschiri, K. Arai, "Effects of Ultrasound on Mass Transfer in Supercritical Extraction", in The 4th International Symposium on Supercritical Fluids, Sendai (JA), 1997.

[116] Yanxiang Gao, Bence Nagy, Xuan Liu, Béla Simándi, Qi Wang, "Supercritical CO2 Extraction of Lutein Esters from Marigold (Tagetes erecta L.) Enhanced by Ultrasound", The Journal of Supercritical Fluids, vol.49, no.3, pp.345-350, 2009.

[117] Ai-jun Hu, Shuna Zhao, Hanhua Liang, Tai-qiu Qiu, Guohua Chen, "Ultrasound Assisted Sup ercritical Fluid Extraction of Oil and Coixenolide from Adlay Seed", Ultrasonics Sonochemistry, vol.14, no.2, pp.219-224, 2007.

[118] Beatriz Díaz-Reinoso, Andrés Moure, Hermínia Domínguez, Juan Carlos Parajó, Antioxidant Extraction by Supercritical Fluids, In. Supercritical Fluid Extraction of Nutraceuticals and Bioactive Compounds, JL Martinez, pp.275-303, CRC Press, Boca Raton, FL, 2008.

[119] Beatriz Díaz-Reinoso, A. Moure, H. Domínguez, J. C. Parajó, "Supercritical CO2 Extraction and Purification of Compound s with Antioxidant Activity", Journal of Agricultural and Food Chemistry, vol.54, no.7, pp.2441-2469, 2006. 
[120] Paulo T. V. Rosa, M. A. A. Meireles, Supercritical and Pressurized Fluid Extraction Applied to the Food Industry, In. Extracting bioactive compounds for food products: theory and applications, MAA Meireles, pp.269-401, CRC Press, Boca Raton, FL, 2009.

[121] C. F. Kuo, J. D. Su, C. H. Chiu, C. C. Peng, C. H. Chang, T. Y. Sung, S. H. Huang, W. C. Lee, C. C. Chyau, "Anti-Inflammatory Effects of Supercritical Carbon Dioxide Extract and its Isolated Carnosic Acid from Rosmarinus officinalis Leaves", Journal of Agricultural and Food Chemistry, vol.59, no.8, pp.3674-3685, 2011.

[122] Priscilla P. Almeida, Natália Mezzomo, Sandra R. S. Ferreira, "Extraction of Mentha spicata L. Volatile Compounds: Evaluation of Process Parameters and Extract Composition", Food and Bioprocess Technology, vol.5, no.2, pp.548-559, 2012.

[123] B. Mandana, A. R. Russly, G. Ali, S. T. Farah, "Antioxidant Activity of Spearmint (Mentha spicata L.) Leaves Extracts by Supercritical Carbon Dioxide (SC-CO2) Extraction", International Food Research Journal, vol.18, no.2, 2011.

[124] Yuefei Wang, Da Sun, Hao Chen, Lisheng Qian, Ping Xu, "Fatty Acid Composition and Antioxidant Activity of Tea (Camellia sinensis L.) Seed Oil Extracted by Optimized Supercritical Carbon Dioxide", International Journal of Molecular Sciences, vol.12, no.11, pp.7708-7719, 2011.

[125] Clara Grosso, Ana Cristina Figueiredo, Jesus Burillo, Ana M. Mainar, José S. Urieta, José G. Barroso, José A. Coelho, António M. F. Palavra, "Composition and Antioxidant Activity of Thymus vulgar is Volatiles: Comparison Between Sup ercritical Fluid Extraction and Hydrodistillation", Journal of Separation Science, vol.33, no.14, pp.2211-2218, 2010.

[126] Patrícia Benelli, Carlos A. S. Riehl, Artur Smânia, Jr., Elza F. A. Smânia, Sandra R. S. Ferreira, "Bioactive Extracts of Orange (Citrus sinensis L. Osbeck) Pomace Obtained by SFE and Low Pressure Techniques: Mathematical Modeling and Extract Composition", Journal of Sup ercritical Fluids, vol.55, no.1, pp.132-141, 2010.

[127] Chi-Huang Chang, Charng-Cherng Chyau, Chiu-Lan Hsieh, Yen-Ying Wu, Yaw-Bee Ker, Hau-Yang Tsen, Robert Y. Peng, "Relevance of Phenolic Diterpene Constituents to Antioxidant Activity of Supercritical CO2 Extract from the Leaves of Rosemary", Natural Product Research, vol.22, no.1, pp.76-90, 2008.

[128] F. P. Lucien, N. R. Foster, "Solubilities of Solid Mixtures in Supercritical Carbon Dioxide: A Review", Journal of Supercritical Fluids, vol.17, no.2, pp.111-134, 2000.

[129] G. Vicente, S. Molina, M. González-Vallinas, M. R. García-Risco, T. Fornari, G. Reglero, A. R. de Molina, "Supercritical Rosemary Extracts, their Antioxidant Activity and Effect on Hep atic Tumor Progression, In Press", Journal of Supercritical Fluids, 2012.

[130] M. Hamburger, D. Baumann, S. Adler, "Supercritical Carbon Dioxide Extraction of Selected Medicinal Plants - Effects of High Pressure and Added Ethanol on Yield of Extracted Substances", Phytochemical Analysis, vol.15, no.1, pp.46-54, 2004.

[131] Patricia F. Leal, Nilson B. Maia, Quirino A. C. Carmello, Rodrigo R. Catharino, Marcos N. Eberlin, M. Angela A. Meireles, "Sweet Basil (Ocimum basilicum) Extracts Obtained by Supercritical Fluid Extraction (SFE): Global
Yields, Chemical Composition, Antioxidant Activity, and Estimation of the Cost of Manufacturing", Food and Bioprocess Technology, vol.1, no.4, pp.326-338, 2008.

[132] L. Casas, C. Mantell, M. Rodríguez, A. Torres, F. A. Macías, E. Martínez de la Ossa, "Effect of the Addition of Cosolvent on the Supercritical Fluid Extraction of Bioactive Compounds from Helianthus annuus L", Journal of Supercritical Fluids, vol.41, no.1, pp.43-49, 2007.

[133] P. Garcia-Salas, A. Morales-Soto, A. Segura-Carretero, A. Fernández-Gutiérrez, "Phenolic-Compound-Extraction Systems for Fruit and Vegetable Samples", Molecules, vol.15, no.12, pp.8813-8826, 2010.

[134] S. D. Yeo, S. J. Park, J. W. Kim, J. C. Kim, "Critical Properties of Carbon Dioxide plus Methanol, plus Ethanol,+1-Propanol, and+1-Butanol", Journal of Chemical and Engineering Data, vol.45, no.5, pp.932-935, 2000.

[135] Juliana M. Prado, Priscilla Carvalho Veggi, M. Angela. A. Meireles, "Extraction Methods for Obtaining Carotenoids from Vegetables", Current Analytical Chemistry, vol. In press, 2013.

[136] Y. N. Lee, C. R. Chen, H. L. Yang, C. C. Lin, C. M. J. Chang, "Isolation and Purification of 3,5-Diprenyl - 4 Hydroxycinnamic Acid (Artepillin C) in Brazilian Propolis by Supercritical Fluid Extractions", Separation and Purification Technology, vol.54, no.1, pp.130-138, 2007.

[137] J. D. C. Francisco, B. Danielsson, A. Kozubek, E. S. Dey, "Extraction of Rye Bran by Supercritical Carbon Dioxide: Influence of Temperature, CO2, and Cosolvent Flow Rates", Journal of Agricultural and Food Chemistry, vol.53, no.19, pp.7432-7437, 2005.

[138] John Shi, Chun Yi, Sophia Jun Xue, Yueming Jiang, Ying Ma, Dong Li, "Effects of Modifiers on the Profile of Lycopene Extracted from Tomato Skins by Supercritical CO2", Journal of Food Engin eering, vol.93, no.4, pp.431-436, 2009.

[139] M. Sun, F. Temelli, "Supercritical Carbon Dioxide Extraction of Carotenoids from Carrot Using Canola Oil as a Continuous Co-Solvent", Journal of Supercritical Fluids, vol.37, no.3, pp.397-408, 2006.

[140] Feliciano Priego-Capote, María Del Pilar Delgado De La Torre, Accelerated Liquid Extraction, In. Natural Product Extraction: Principles and Applications, MA Rostagno, JM Prado, pp.157-195, Royal Soc Of Chemistry, 2013.

[141] W. Li, Z. Wang, Y. P. Wang, C. Jiang, Q. Liu, Y. S. Sun, Y. N. Zheng, "Pressurised Liquid Extraction Combining LC-DAD -ESI/MS Analysis as an Alternative Method to Extract Three Major Flavones in Citrus reticulata 'Chachi' (Guan gchenpi)", Food Chemistry, vol.130, no.4, pp.1044-1049, 2012.

[142] P. Budrat, A. Shotipruk, "Enhanced Recovery of Phenolic Compounds from Bitter Melon (Momordica charantia) by Subcritical Water Extraction", Separation and Purification Technology, vol.66, no.1, pp.125-129, 2009.

[143] C. I. Cheigh, E. Y. Chung, M. S. Chung, "Enhanced Extraction of Flavanones Hesperidin and Narirutin from Citrus unshiu Peel Using Subcritical Water", Journal of Food Engineering, vol.110, no.3, pp.472-477, 2012.

[144] L. St'avikova, M. Polovka, B. Hohnova, P. Karasek, M. Roth, "Antioxidant Activity of Grape Skin Aqueous Extracts from Pressurized Hot Water Extraction Combined with Electron 
Paramagnetic Resonance Spectroscopy", Talanta, vol.85, no.4, pp.2233-2240, 2011.

[145] J. W. King, R. D. Grabiel, Isolation of Polyphenolic Compounds from Fruits or Vegetable Utilizing Sub-Critical Water Extraction, US7208181-B1, Washington, DC (USA), 2007.

[146] J. M. Luque-Rodriguez, M. D. Luque de Castro, P. Perez-Juan, "Dynamic Superheated Liquid Extraction of Anthocyanins and other Phenolics from Red Grape Skins of Winemaking Residues", Bioresource Technology, vol.98, no.14, pp.2705-2713, 2007.

[147] J. E. Cacace, G. Mazza, "Mass Transfer Process During Extraction of Phenolic Compounds from Milled Berries", Journal of Food Engineering, vol.59, no.4, pp.379-389, 2003.

[148] A. Kirca, M. Özkan, B. Cemeroğlu, "Effects of Temperature, Solid Content and $\mathrm{pH}$ on the Stability of Black Carrot Anthocyanins", Food Chemistry, vol.101, no.1, pp.212-218, 2006.

[149] T. L. Miron, M. Plaza, G. Bahrim, E. Ibáñez, M. Herrero, "Chemical Composition of Bioactive Pressurized Extracts of Romanian Aromatic Plants", Journal of Chromatography A, vol.1218, no.30, pp.4918-4927, 2011.

[150] D. T. Santos, P. C. Veggi, M. A. A. Meireles, "Optimization and Economic Evaluation of Pressurized Liquid Extraction of Phenolic Compounds from Jabuticaba Skins", Journal of Food Engin eering, vol.108, no.3, pp.444-452, 2012.

[151] G. Garrote, H. Domínguez, J. C. Parajó, "Production of Substituted Oligosaccharides by Hydrolytic Processing of Barley Husks", Industrial and Engineering Chemistry Research, vol.43, no.7, pp.1608-1614, 2004.

[152] A. Moure, H. Domínguez, J. C. Parajó, "Antioxidant Activity of Liquors from Aqueous Treatments of Pinus radiata Wood", Wood Science and Technology, vol.39, no.2, pp.129-139, 2005.

[153] A. Mustafa, C. Turner, "Pressurized Liquid Extraction as a Green Approach in Food and Herbal Plants Extraction: A Review", Analytica Chimica Acta, vol.703, no.1, pp.8-18, 2011.

[154] S. Rodríguez-Rojo, A. Visentin, D. Maestri, M. J. Cocero, "Assisted Extraction of Rosemary Antioxidants with Green Solvents", Journal of Food Engineering, vol.109, no.1, pp.98-103, 2012.

[155]Zill-e Huma, Maryline Abert Vian, Anne-Sylvie Fabiano-Tixier, Mohamed Elmaataoui, Olivier Dangles, Farid Chemat, "A Remarkable Influence of Microwave Extraction: Enhancement of Antioxidant Activity of Extracted Onion Varieties", Food Chemistry, vol.127, no.4, pp.1472-1480, 2011.

[156] Xueling Zheng, Benguo Liu, Limin Li, Xiaoai Zhu, "Microwave-Assisted Extraction and Antioxidant Activity of Total Phenolic Compounds From Pomegranate Peel", Journal of Medicinal Plants Research, vol.5, no.6, pp.1004-1011, 2011.

[157] Tameshia S. Ballard, Parameswarakumar Mallikarjunan, Kequan Zhou, Sean O'Keefe, "Microwave - Assisted Extraction of Phenolic Antioxidant Compounds from Peanut Skins", Food Chemistry, vol.120, no.4, pp.1185-1192, 2010.
[158] Yinping Li, George K. Skouroumounis, Gordon M. Elsey, Dennis K. Taylor, "Microwave-Assistance Provides Very Rapid and Efficient Extraction of Grape Seed Polyphenols", Food Chemistry, vol.129, no.2, pp.570-576, 2011.

[159] Jiangfeng Song, Dajing Li, Chunquan Liu, Ying Zhang, "Optimized Microwave-Assisted Extraction of Total Phenolics (TP) from Ipomoea batatas Leaves and its Antioxidant Activity", Innovative Food Science \& Emerging Technologies, vol.12, no.3, pp.282-287, 2011.

[160] N. Sutivisedsak, H. N. Cheng, J. L. Willett, W. C. Lesch, R. R. Tangsrud, Atanu Biswas, "Microwave-Assisted Extraction of Phenolics from Bean (Phaseolus vulgaris L.)", Food Research International, vol.43, no.2, pp.516-519, 2010.

[161] Xiao-Juan Li, Wei Wang, Meng Luo, Chun-Ying Li, Yuan-Gang $\mathrm{Zu}$, Pan-Song $\mathrm{Mu}$, Yu-Jie Fu, "Solvent-Free Microwave Extraction of Essential Oil from Dryopteris Fragrans and Evaluation of Antioxidant Activity", Food Chemistry, vol.133, no.2, pp.437-444, 2012.

[162] V. Camel, "Microwave-Assisted Solvent Extraction of Environmental Samples", Trends in Analytical Chemistry, vol.19, no.4, pp.229-248, 2000.

[163] M. D. Esclapez, J. V. García-Pérez, A. Mulet, J. A. Cárcel, "Ultrasound-Assisted Extraction of Natural Products", Food Engineering Reviews, vol.3, no.2, pp.108-120, 2011.

[164] Li Yang, Ya-Lan Cao, Jian-Guo Jiang, Qing-Sheng Lin, Jian Chen, Liang Zhu, "Response Surface Optimization of Ultrasound-Assisted Flavonoids Extraction from the Flower of Citrus aurantium L. var. Amara Engl", Journal of Separation Science, vol.33, no.9, pp.1349-1355, 2010.

[165] Guangyan Pan, Guoyong Yu, Chuanhe Zhu, Julin Qiao, "Optimization of Ultrasound-Assisted Extraction (UAE) of Flavonoids Compounds (FC) from Hawthorn Seed (HS)", Ultrasonics Sonochemistry, vol.19, no.3, pp.486-490, 2012.

[166] L. Galvan D'Alessandro, K. Kriaa, I. Nikov, K. Dimitrov, "Ultrasound Assisted Extraction of Polyphenols from Black Chokeberry", Separation and Purification Technology, vol.93, pp.42-47, 2012.

[167] Reza Tabaraki, Ashraf Nateghi, "Optimization of UltrasonicAssisted Extraction of Natural Antioxidants from Rice Bran Using Response Surface Methodology", Ultrasonics Sonochemistry, vol.18, no.6, pp.1279-1286, 2011.

[168] L. Yang, H. Wang, Y. G. Zu, C. Zhao, L. Zhang, X. Chen, Z. Zhang, "Ultrasound-Assisted Extraction of the Three Terpenoid Indole Alkaloids Vindoline, Catharanthine and Vinblastine from Catharanthus roseus Using Ionic Liquid Aqueous Solutions", Chemical En gin eering Journal, vol.172, no.2-3, pp.705-712, 2011.

[169] P. N. Diouf, T. Stevanovic, Y. Boutin, "The effect of Extraction Process on Polyphenol Content, Triterpene Composition and Bioactivity of Yellow Birch (Betula alleghaniensis Britton) Extracts", Industrial Crops and Products, vol.30, no.2, pp.297-303, 2009.

[170] C. Y. Lien, C. F. Chan, Y. C. Lai, C. L. Huang, W. C. Liao, "Ultrasound-Assisted Anthocyanin Extraction of Purple Sweet Potato Variety TNG73, Ipomoea batatas, L", Separation Science and Technology, vol.47, no.8, pp.1241-1247, 2012. 
[171] Jelena D. Mladenovic, PavleZ. Maskovic, Rados M. Pavlovic, Blaga C. Radovanovic, Gordana Acamovic-Dokovic, Milica S. Cvijovic, "Antioxidant Activity of Ultrasonic Extracts of Leek Allium porrum L", Hemijska Industrija, vol.65, no.4, pp.473-477, 2011.

[172] K. Vilkhu, R. Mawson, L. Simons, D. Bates, "Applications and Opportunities for Ultrasound Assisted Extraction in the Food Industry - A Review", Innovative Food Science and Emerging Technologies, vol.9, no.2, pp.161-169, 2008.

[173] Sandra B. Glisic, Mihajlo Ristic, Dejan U. Skala, "The Combined Extraction of Sage (Salvia officinalis L.): Ultrasound Followed by Supercritical CO2 Extraction", Ultrasonics Sonochemistry, vol.18, no.1, pp.318-326, 2011.

[174] E. Riera, Y. Golas, A. Blanco, J. A. Gallego, M. Blasco, A. Mulet, "Mass Transfer Enhancement in Supercritical Fluids Extraction by Means of Power Ultrasound", Ultrasonics Sonochemistry, vol.11, no.3-4, pp.241-244, 2004.

[175] S. Balachandran, S. E. Kentish, R. Mawson, M. Ashokkumar, "Ultrasonic Enhancement of the Sup ercritical Extraction from Ginger", Ultrasonics Sonochemistry, vol.13, no.6, pp. 471 479, 2006.

[176] Philipe dos Santos, Ana C. A guiar, Camila A. Rezende, Julian Martínez, "Supercritical Carbon Dioxide Extraction of Oleoresin from Malagueta Pepper (Capsicum frutescens L.) Enhanced by Ultrasound", in III Iberoamerican Conference on Supercritical Fluids, Cartagena de Indias (CO), 2013.

[177] M. E. M. Braga, P. F. Leal, J. E. Carvalho, M. A. A. Meireles, "Comparison of Yield, Composition, and Antioxidant Activity of Turmeric (Curcuma longa L.) Extracts Obtained Using Various Techniques", Journal of Agricultural and Food Chemistry, vol.51, no.22, pp.6604-6611, 2003.

[178] W. Guan, S. Li, R. Yan, S. Tang, C. Quan, "Comparison of Essential Oils of Clove Buds Extracted with Supercritical Carbon Dioxide and Other Three Traditional Extraction Methods", Food Chemistry, vol.101, no.4, pp.1558-1564, 2007.

[179] S. Machmudah, Zakaria, S. Winardi, M. Sasaki, M. Goto, N. Kusumoto, K. Hayakawa, "Lycopene Extraction from Tomato Peel By-Product Containing Tomato Seed Using Supercritical Carbon Dioxide", Journal of Food Engineering, vol.108, no.2, pp.290-296, 2012.

[180] C. Yi, J. Shi, S. J. Xue, Y. M. Jiang, D. Li, "Effects of Supercritical Fluid Extraction Parameters on Lycopene Yield and Antioxidant Activity", Food Chemistry, vol.113, no.4, pp.1088-1094, 2009

[181] K. L. Nyam, C. P. Tan, R. Karim, O. M. Lai, K. Long, Y. B. C. Man, "Extraction of Tocopherol-Enriched Oils from Kalahari Melon and Roselle Seeds by Supercritical Fluid Extraction (SFE-CO2)", Food Chemistry, vol.119, no.3, pp.1278-1283, 2010.

[182] H. L. N. Lau, Y. M. Choo, A. N.Ma, C. H. Chuah, "Selective Extraction of Palm Carotene and Vitamin E from Fresh Palm-Pressed Mesocarp Fiber (Elaeis guineensis) Using Supercritical CO2", Journal of Food Engineering, vol.84, no.2, pp.289-296, 2008.

[183] K. C. Zancan, M. O. M. Marques, A. J. Petenate, M. A. A Meireles, "Extraction of Ginger (Zingiber officinale roscoe) Oleoresin with $\mathrm{CO} 2$ and Co-Solvents: A Study of the
Antioxidant Action of the Extracts", Journal of Supercritical Fluids, vol.24, no.1, pp.57-76, 2001.

[184] L. F. De França, G. Reber, M. A. A. Meireles, N. T. Machado, G. Brunner, "Supercritical Extraction of Carotenoids and Lipids from Buriti (Mauritia flexuosa), a Fruit from the Amazon Region", Journal of Sup ercritical Fluids, vol.14, no.3, pp.247-256, 1999.

[185] G. L. Filho, V. V. De Rosso, M. A. A.Meireles, P. T. V. Rosa, A. L. Oliveira, A. Z. Mercadante, F. A. Cabral, "Sup ercritical $\mathrm{CO} 2$ Extraction of Carotenoids from Pitanga Fruits (Eugenia uniflora L.)", Journal of Supercritical Fluids, vol.46, no.1, pp.33-39, 2008.

[186] M. Polovka, L. Št’avíková, B. Hohnová, P. Karásek, M. Roth, "Offline Combination of Pressurized Fluid Extraction and Electron Paramagnetic Resonance Spectroscopy for Antioxidant Activity of Grape Skin Extracts Assessment", Journal of Chromatography A, vol.1217, no.51, pp.7990-8000, 2010.

[187] L. Howard, N. Pandjaitan, "Pressurized Liquid Extraction of Flavonoids from Spinach", Journal of Food Science, vol.73, no.3, pp.C151-C157, 2008.

[188] D. L. Luthria, "Optimization of Extraction of Phenolic Acids from a Vegetable Waste Product Using a Pressurized Liquid Extractor", Journal of Functional Foods, no.4, pp.842-850, 2012.

[189] P. Dobiáš, P. Pavlíková, M. Adam, A. Eisner, B. Beňová, K. Ventura, "Comparison of Pressurised Fluid and Ultrasonic Extraction Methods for Analysis of Plant Antioxidants and their Antioxidant Capacity", Central European Journal of Chemistry, vol.8, no.1, pp.87-95, 2010.

[190] H. Wijn gaard, N. Brunton, "The Optimization of Extraction of Antioxidants from Apple Pomace by Pressurized Liquids", Journal of Agricultural and Food Chemistry, vol.57, no.22, pp.10625-10631, 2009.

[191] S. Jokić, M. Cvjetko, D. Božić, S. Fabek, N. Toth, J. Vorkapić-Furač, I. R. Redovniković, "Optimisation of Microwave-Assisted Extraction of Phenolic Compounds from Broccoli and its Antioxidant Activity", International Journal of Food Science and Technology, 2012.

[192] K. Krishnaswamy, V. Orsat, Y. Gariépy, K. Thangavel, "Optimization of Microwave-Assisted Extraction of Phenolic Antioxidants from Grape Seeds (Vitis vinifera)", Food and Bioprocess Technology, pp.1-15, 2012.

[193] Monica Gallo, Rosalia Ferracane, Giulia Graziani, Alberto Ritieni, Vincenzo Fogliano, "Microwave Assisted Extraction of Phenolic Compounds from Four Different Spices", Molecules, vol.15, no.9, pp.6365-6374, 2010.

[194] R. Tabaraki, E. Heidarizadi, A. Benvidi, "Optimization of Ultrasonic-Assisted Extraction of Pomegranate (Punica granatum L.) Peel Antioxidants by Response Surface Methodology", Separation and Purification Technology, vol.98, pp.16-23, 2012.

[195] M. B. Hossain, N. P. Brunton, A. Patras, B. Tiwari, C. P. O'Donnell, A. B. Martin-Diana, C. Barry-Ry an, "Optimizatio $\mathrm{n}$ of Ultrasound Assisted Extraction of Antioxidant Compounds from Marjoram (Origanum majorana L.) Using Response Surface Methodology", Ultrasonics Sonochemistry, vol.19, no.3, pp.582-590, 2012. 
[196] H. V. Annegowda, R. Bhat, L. Min-Tze, A. A. Karim, S. M. Mansor, "Influence of Sonication Treatments and Extraction Solvents on the Phenolics and Antioxidants in Star Fruits", Journal of Food Science and Technology, vol.49, no.4, pp.510-514, 2012.

[197] H. V. Le, V. M. L. Van, "Comparison of Enzyme-Assisted and Ultrasound-Assisted Extraction of Vitamin $\mathrm{C}$ and Phenolic Compounds from Acerola (Malpighia emarginata DC.) Fruit", International Journal of Food Science and Technology, vol.47, no.6, pp.1206-1214, 2012.

[198] X. Jun, Z. Shuo, L. Bingbing, Z. Rui, L. Ye, S. Deji, Z. Guofeng, "Separation of major catechins from green tea by ultrahigh pressure extraction", International Journal of Pharmaceutics, vol.386, no.1-2, pp.229-231, 2010.

[199] Yu-Wen Hsu, Chia-Fang Tsai, Wen-Kang Chen, Yung-Chyuan Ho, Fung-Jou Lu, "Determination of Lutein and Zeaxanthin and Antioxidant Capacity of Supercritical Carbon Dioxide Extract from Daylily (Hemerocall is disticha)", Food Chemistry, vol.129, no.4, pp.1813-1818, 2011.

[200] Wei Xu, Kedan Chu, Huang Li, Lidian Chen, Yuqin Zhang, Xuchong Tang, "Extraction of Lepidium apetalum Seed Oil Using Supercritical Carbon Dioxide and Anti-Oxidant Activity of the Extracted Oil", Molecules, vol.16, no.12, pp.10029-10045, 2011.

[201] Mohd Sabri Pak-Dek, Azizah Osman, Najla Gooda Sahib, Nazamid Saari, Masturah Markom, Azizah Abdul Hamid, Farooq Anwar, "Effects of Extraction Techniques on Phenolic Components and Antioxidant Activity ofMengkudu (Morinda citrifolia L.) Leaf Extracts", Journal of Medicinal Plants Research, vol.5, no.20, pp.5050-5057, 2011.
[202] Mi-Bo Kim, Jae-Sung Park, Sang-Bin Lim, "Antioxidant Activity and Cell Toxicity of Pressurised Liquid Extracts from 20 Selected Plant Species in Jeju, Korea", Food Chemistry, vol.122, no.3, pp.546-552, 2010.

[203] Ying Xie, Jinyong Peng, Guorong Fan, Yutian Wu, "Chemical Composition and Antioxidant Activity of Volatiles from Patrinia Villosa Juss Obtained by Optimized Supercritical Fluid Extraction", Journal of Pharmaceutical and Biomedical Analy sis, vol.48, no.3, pp.796-801, 2008.

[204] Aziza Kamal Genena, Haiko Hense, Artur Smânia Junior, Simone Machado de Souza, "Rosemary (Rosmarinus officinalis) - A Study of the Composition, Antioxidant and Antimicrobial Activities of Extracts Obtained with Supercritical Carbon Dioxide", Ciencia E Tecnologia De Alimentos, vol.28, no.2, pp.463-469, 2008.

[205] Ivana Karabegovic, Milena Nikolova, Dragan Velickovic, Sasa Stojicevic, Vlada Veljkovic, Midorag Lazic, "Comparison of Antioxidant and Antimicrobial Activities of Methanolic Extracts of the Artemisia sp Recovered by Different Extraction Techniques", Chinese Journal of Chemical Engineering, vol.19, no.3, pp.504-511, 2011.

[206] Keyvan Dastmalchi, H. T. Damien Dorman, Paivi P. Oinonen, Yusrida Darwis, Into Laakso, Raimo Hiltunen, "Chemical Composition and in Vitro Antioxidative Activity of a Lemon Balm (Melissa officinal is L.) Extract", Lwt-Food Science and Technology, vol.41, no.3, pp.391-400, 2008.

[207] Yingming Pan, Chunhuan He, Hengshan Wang, Xiaowen Ji, Kai Wang, Peizhen Liu, "Antioxidant Activity of Microwave-Assisted Extract of Buddleia officinalis and its Major Active Component", Food Chemistry, vol.121, no.2, pp.497-502, 2010. 